\title{
Tax Incentives \& Microfinance Business in Nigeria: A Study of Selected Microfinance Banks in Rivers State
}

\author{
Ironkwe, Uwaoma I. Ph.D ${ }^{1}$, NNAJI, Paul O ${ }^{2}$ \\ ${ }^{I}$ Department of Accounting, Faculty of Management Science University of Port Harcourt, Rivers State, Nigeria. \\ ${ }^{2}$ Department of Accounting, Faculty of Management Science University of Port Harcourt, Rivers State, Nigeria.
}

\begin{abstract}
This study is carried out to empirically ascertain the extent to which tax incentives would enhance realization of core objectives of regulated microfinance business in Nigeria with a focus on Rivers State. Research questions were raised, hypotheses formulated and related literature reviewed. Primary data were collected from the shareholders, managers, key employees, customers and external auditors of 19 Microfinance Banks in Rivers State through questionnaire and participant observation. The questionnaire before its administration was subjected to validity and reliability test. The test re-test method using the Kendall coefficient of concordance gave a result of 0.84 indicating a strong reliability of the instrument. The data generated were analyzed and tabulated, Spearman's Rank Correlation Coefficient and $Z$ test statistics were adopted in testing the hypotheses formulated. The findings are that tax incentives have significant and positive relationship with the business performance of Microfinance Banks in Nigeria. Despite high tax burdens other major factors militating against microfinance business in Nigeria are weak infrastructure, poor corporate governance and loan defaults. It is recommended that Government at all levels should grant five years tax holidays to Microfinance Banks especially at their infancy and vulnerable stages to enable them stabilize and effectively play the role of change agents in the poverty eradication, job creation and financial inclusion crusades. The Microfinance Bank Managers should also embrace annual tax planning as a way of managing their tax burdens with or without tax incentives.
\end{abstract}

Keywords: Capital formation, Credit delivery, Financial inclusion, Microfinance Banks, Nigeria, and Tax Incentives

\section{Introduction}

Tax is a compulsory payment imposed by government on her citizens without a corresponding quid pro quo. Quid pro quo in this context means direct or specific benefit either in cash or in kind. Individual and corporate citizens of nations engage in plethora of economic activities in the areas of mining, manufacturing, agriculture, construction, commerce and industry in the form of trade, vocation, profession and occupation which enable them to earn varying incomes such as rents, wages/salaries, interests, dividends and profits as well as the ownership of assets.

What government does, therefore, is to appropriate a certain portion of the rents, wages, interests, dividends and profits that accrue to the productive citizenry in order to build her (government's) own revenue base. Government needs income, otherwise called revenue, in order to undertake her socio-political, administrative, regulatory and developmental functions, which would not be properly handled if left in the hands of the private sector of the economy.

Specifically, some of the key reasons behind the collection of tax revenue by government include:

i) To cover the cost of general administration, internal and external defence, maintenance of law and order and the social services.

ii) To reduce disparities in the income distribution in the economy.

iii) To control the consumption of goods and services considered non-essential or harmful.

iv) To check inflation by reducing the volume of purchasing power.

v) To service national debts both foreign and domestic.

vi) To provide subsidies in favour of selected sectors of the economy.

vii) To implement government policies and programmes.

viii) To execute critical infrastructures in the economy such as power, roads, bridges, rail and ports.

Tax gives rise to taxation which is a system of charging and collecting the taxes by relevant tax authorities of the federal, state or local governments in accordance with established criteria, standards and statutes. The basic distinction between taxes and other forms of government revenue as posited by Anyafo (1996:53) is the element of compulsion involved; thus the tax payer has no choice in the matter if considered eligible for payment; on the basis of the pre-determined criteria.

Taxation as a major part and parcel of the public finance can be said to be as old as mankind. Anyafo (1996:27) points out that an excursion to the cradle of human civilization easily unearths the fact 
that the history of public finance dates back more than 7,000 years and was also associated with the earliest organized governments like the Babylonians, Egyptians, Chinese, Greeks and the Romans. It was recorded in the scriptures (Matthew 17:24-27) that our Lord and Saviour, Jesus Christ, participated in tax payment which goes down to stress the spiritual recognition of tax payment as a civic obligation.

Tax payments had existed in different fashions in traditional Nigeria before the European incursion in the 19th century. Before the annexing of Lagos in 1860 and the amalgamation of Northern and Southern protectorates in 1914, several political entities existed in the sub-Saharan Africa. Such included ancient Ghana, Mali, Songhai and Kanem Bornu Empires. Others were Hausa City States, Kwarafa Kingdom, Bini Kingdom, Oyo Kingdom, etc. The people of these parts had been used to elaborate systems of taxation and the payment of tributes to the Chiefs and Natural Rulers. According to Anyafo (1996:33), there were existence of jangali in the Northern Nigeria which is a capitation tax on cattlle belonging to the nomads as well as community taxes while the Oyos, Egbas, Binis and others in the south were used to the payment of tributes to their Obas, Obis and Igwes.

Nigeria, since independence, has evolved more sophisticated system of taxation by way of legislations, administration and fiscal federalism. With 36 states in its kitty, a federal capital territory and 774 local government areas, experts have maintained that virtually everything that accrue to the federation account is tax payers money.

The administrative machinery of taxation in Nigeria is undertaken by the Joint Tax Board (JTB), the Federal Board of Inland Revenue, the Nigeria Custom Service, the States Boards of Internal Revenue, Local Governments Revenue Committees, and the Joint States Revenue Committees. The present tax legislations in force in Nigeria are Company Income Act of 2004, Federal Inland Revenue Service Amendment Act 2007, Personal Income Tax Amendment Act 2011, Petroleum Profit Tax Act 2004, Value Added Tax Act 2004, Capital Gains Tax Act of 2004 etc.

Tax incentive can therefore be described as government's policies put in place to encourage certain individuals or corporate bodies in their businesses by reducing or removing their tax obligations. Tax incentives in Nigeria come in different ways thus;

i) Tax holidays to pioneer industries in Agric and Manufacturing for 3-5 years,

ii) Tax relief on loans granted to Nigerian companies,

iii) Tax rebates for downstream gas utilization projects,

iv) Loss reliefs

v) VAT exemption on exported goods and services,

vi) VAT exemption on the services of Community Banks

vii) Tax free zones and trade free zones to mention but fee.

Tax incentives according to Adedokun (2001:142) is "the reduction in the effective tax burden on the favoured economic activity as against that currently imposed upon it, with the hope that the reduction in government revenue would bring an expected expansion of the national economy and ultimately bring a relative increase in total revenue from such broadened economic basis".

Tax incentives according to Gberegbe (2007: 18) are those devices used by the government to encourage investments. They are essentially designed to promote industrialization especially in the area of manufacturing activities. Examples are accelerated depreciation, tax holidays and import duty relief.

Microfinance business is the provision of simple, flexible, diversified, affordable and sustainable financial services to the active poor, small and medium scale entrepreneurs (SMEs), co-operative societies, informal selfhelp solidarity groups, market traders, farmers, fishermen, artisans, NGOs, civil servants and corporate bodies. Such services include micro savings, micro/medium credits, payment services, domestic fund transfers and micro insurance.

As stated in Revised Microfinance Certification Study Manual (2011:37), microfinance services are provided by three types of institutions:

- Formal institutions, such as microfinance banks, rural banks and deposit money banks;

- Semi-formal institutions, such as non-governmental organizations (NGOs) and cooperatives;

- Informal sources such as Rotating savings and Credit Associations

(ROSCA), Accumulated Savings and Credit Associations (ASCA), daily savings collectors (also known as door-to-door 'bankers') money lenders and shopkeepers.

Institutional microfinance is defined to include microfinance services provided by both formal and semi-formal institutions. Microfinance institutions are defined as institutions whose major business is the provision of microfinance services.

Microfinance clients are mostly self-employed, low-income entrepreneurs in both urban and rural areas. Clients are often traders, street vendors, small farmers, service providers (hairdressers, cart pushers), artisans and small producers, such as black-smiths and seamstresses. Their activities provide income (often from more than one activity) for the individuals and their households. Although they are often poor, they are 
generally not considered to be the "poorest of the poor". These micro-entrepreneurs need a safe and secure place to keep their excess income; they require credit for business expansion or growth and require access to other financial services like insurance (usually provided through informal network of family and friends).

The concept of microfinance is not new. Savings and credit groups that have operated for centuries include the "Susus" of Ghana, "Ajo" (Yoruba), "Akawo" (Igbo) and "Adashe" (Hausa) in Nigeria. "Chit funds" in India, "Tandas" in Mexico, "Arisan" in Indonesia, "Cheetu" in Sri Lanka, and "Pasanaku" in Bolivia, as well as numerous savings clubs and burial societies found all over the world.

Formal Credit and savings institutions for the poor have also been around for decades, providing customers who were traditionally neglected by deposit money banks, a way to obtain financial services through cooperatives and development finance institutions. For many observers, microfinance - a collection of banking practices built around providing small loans (typically without collateral) and accepting tiny savings deposit - is nothing short of a revolution or a paradigm shift.

In order to enhance the flow of financial services to Nigerian active poor, Government has in the past, initiated a series of publicly-financed urban/rural micro credit programmes and policies. Notable among such programmes were the Rural Banking Programme, sectoral allocation of credits at concessionary interest rates, and the Agricultural Credit Guarantee Scheme (ACGS). Other institutional arrangements were the establishment of the Nigerian Agricultural and Co-operative Bank Limited (NACB), the National Directorate of Employment (NDE), the Nigerian Agricultural Insurance Corporation (NAIC), the Peoples Bank of Nigeria (PBN), the Community Banks (CBs), and the Family Economic Advancement Programme (FEAP).

In 2000, Government merged the NACB with the PBN and FEAP to form the Nigerian Agricultural Cooperative and Rural Development Bank Limited (NACRDB) to enhance the provision of finance to the agricultural sector. It also created the National Poverty Eradication Programme (NAPEP) with the mandate of providing financial services to alleviate poverty. (CBN, 2005:4).

In December, 2005, the then president, Olusegun Obasanjo launched the new Microfinance policy to usher in Microfinance Banks. Microfinance banks are therefore banks licensed and supervised by Central Bank of Nigeria $(\mathrm{CBN})$ to deliver microfinance services. As at $31^{\text {st }}$ December, 2012 there are over 800 licenced microfinance banks in Nigeria 25 of which belong to Rivers State.

This Research work entitled Tax Incentives and Microfinance Business in Nigeria is a study carried out to empirically ascertain the extent to which tax incentives would enhance realization of core objectives of microfinance services in Nigeria with a focus on Rivers State.

\subsection{Statement Of Problem}

It is disturbing to note that despite the goal of Federal government for diversified, affordable and reliable financial services to the active poor and small business operators that would boost financial inclusion and reduce poverty, many licenced microfinance institutions in Rivers State are not living up to expectations.

Specifically, they have posted sub-optimal performances in micro credit delivery, collection of unbanked/under-banked deposits, domestic funds transfers and social intermediation which have often resulted to low profitability, poor liquidity, poor asset qualities, capital impairment and total distress, no wonder the poverty and unemployment indices in the country is on the upward trend rather than diminishing.

The sub-optimal performances could be attributed to a number of variables including high tax burdens. The burdens which constitute a chunk of the problem come through the $30 \%$ company income tax on profits, $10 \%$ withholding tax on placements with Deposit Money Banks, 5\% value added tax on commission earned on microfinance services, taxes on microfinance dividends paid, State government development levies and business premises annual fees as well as multiple taxes imposed by local governments. Reduction or waiver of these taxes by way of incentives to the Microfinance Banks shall be a step in the right direction. It is against this backdrop that this study intends to investigate the effect of tax incentives on microfinance business in Nigeria.

\subsection{Objectives Of The Study}

The main objective of this study is to examine existing tax issues on microfinance business in Nigeria and to determine the effects thereon. Specifically, this study aims at achieving the following objectives;

i) To evaluate the extent to which tax holidays affect the profitability of microfinance banks in Nigeria;

ii) To examine the effect of tax holidays on capital formation of microfinance banks in Nigeria;

iii) To determine the extent to which tax holidays impact on the financial inclusion roles of microfinance banks in Nigeria;

iv) To evaluate the effect of tax holidays on the credit delivery of microfinance banks in Nigeria;

v) To ascertain the extent to which tax holidays impact on the social intermediation roles of microfinance banks in Nigeria; 
Tax Incentives \& Microfinance Business In Nigeria: A Study Of Selected Microfinance Banks In ..

\subsection{Research Questions}

Based on the objectives of this study, the following research questions were addressed;

i) To what extent does tax holidays affect the profitability of microfinance banks in Nigeria;

ii) What is the effect of tax holidays on capital formation of microfinance banks in Nigeria;

iii) To what extent does tax holidays impact on the financial inclusion roles of microfinance banks in Nigeria;

iv) What is the effect of tax holidays on the credit delivery of microfinance banks in Nigeria;

v) To what extent does tax holidays impact on the social intermediation roles of microfinance banks in Nigeria;

\subsection{Conceptual Framework}

The conceptual framework of this study is based on a presumed casual relationship between the Tax incentives (independent variable) and Microfinance business in Nigeria (dependent variable). The constructs of tax incentives are five years tax holidays, four years loss reliefs, exempting of withholding tax (WHT) on shareholders' dividends payable, exemption of WHT on clients deposit interests and exemption of Value added tax on Microfinance services; while the microfinance business has profitability, capital formation, financial inclusion, credit delivery and social intermediation as its own constructs.

It is hypothesized that each component of tax incentives would impact on each component of microfinance business. The relationship between tax incentives and microfinance business is moderated by factors such as government regulations, technology and client size.

It is also hypothesized that the moderating variables mediate on the influence of tax incentives on microfinance business in Nigeria. In other words, the tax incentives to be granted to Microfinance Banks will be moderated by the regulatory regimes, technology and client size. This is represented in the figure below.

Figure 1: Conceptual Model of Tax Incentives and Microfinance Business

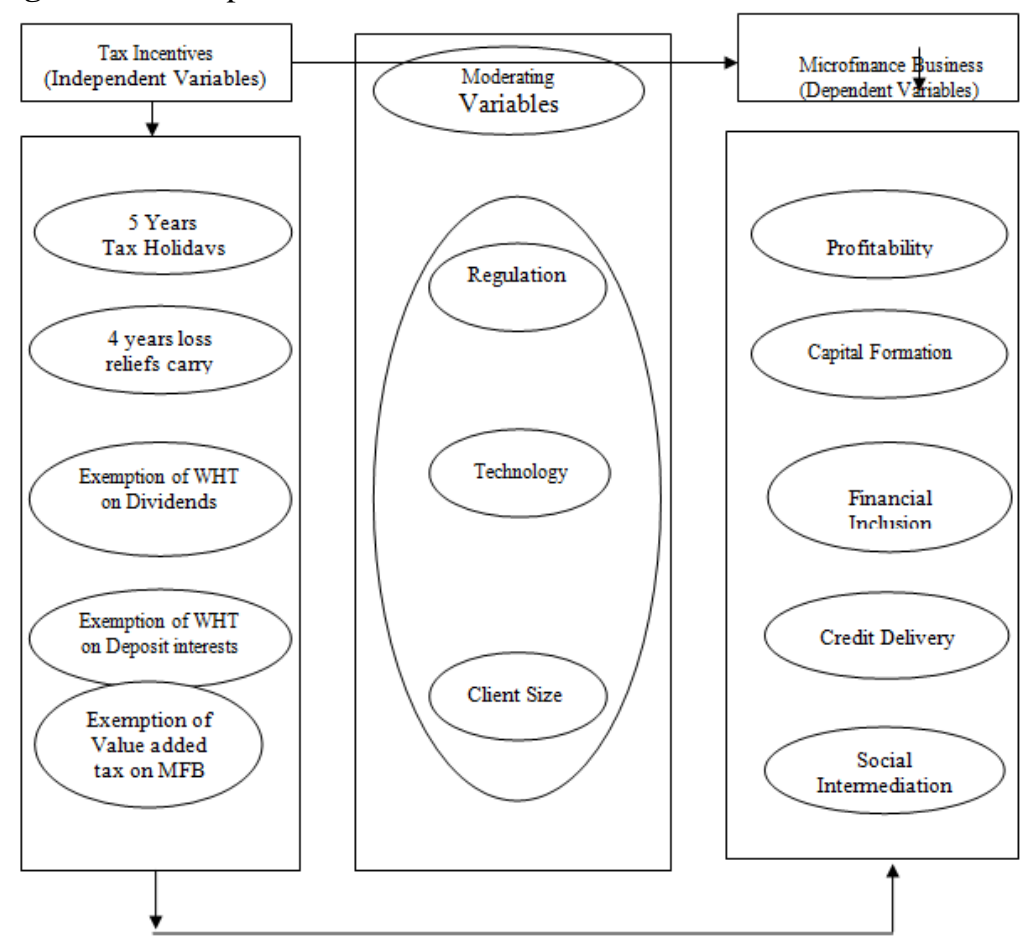

Source: Researchers Conceptualization 2014

\subsection{Hypotheses}

$\mathbf{H o}_{1}$ : Five years tax holidays will not significantly affect the profitability of microfinance banks in Nigeria.

$\mathrm{Ho}_{2}$ : Five years tax holidays will not significantly impact on the capital formation of microfinance banks in Nigeria.

$\mathrm{Ho}_{3}$ : Five years tax holidays will not significantly enhance the financial inclusion roles of microfinance banks in Nigeria.

Ho $_{4}$ : Five years tax holidays will not significantly enhance the credit delivery of microfinance banks in Nigeria.

Ho$_{5}$ : Five years tax holidays will not significantly enhance the social intermediation roles of microfinance banks in Nigeria. 


\subsection{Significance of the Study}

As already stated above, the study is an applied research which attempts to proffer practical solutions that could ameliorate tax burdens militating against microfinance business in Nigeria.

The work will add to the existing literature and would be of interest to the Microfinance banks and all the stake holders in the Microfinance sub-sector of the Nigerian financial system. Finance Consultants, Professional bodies, academics and fellow students in the field of Management Sciences with specialization in accountancy and finance shall also benefit from this work. International Donor or Lending Agencies investing or intending to invest in poverty eradication schemes in Nigeria would also find this piece of work very useful.

\subsection{Scope of the Study}

This study is limited to the operations of microfinance banks in Nigeria with a focus on Rivers State for a period of five years $(2008-2012)$. It is an investigation into how tax incentives could be applied as an economic tool to boost sustainability of microfinance banks in playing the roles of financial inclusion, credit delivery and social intermediation to their target clients. It is not concerned with other dimensions of the industry.

\subsection{Limitations of the Study}

In course of this study, the researcher was limited by certain factors such as;

i) Dearth of study materials - The researcher could not lay hand on desired number of text books, journals and other publications on the topic. Several attempts to consult books in the library proved little success.

ii) Logistic Problems - It was quite difficult going round the Microfinance banks operating in Rivers State for the purpose of collecting primary data from their managers and clients.

iii) Biasness of Respondents - Many of the respondents met did not understand the objective of the research work and therefore were unwilling to give out much desired information.

iv) Time - There was no sufficient time to carry out elaborate study as desired on the subject matter due to time conflict between the researcher's job and the research work.

v) Cost - The cost of the research was enormous.

\subsection{Definition of Terms}

Capital Formation: Building up the shareholders fund through capital injections and retained profits

Financial Inclusion: Making banking services available to all bankable populace in both urban and rural areas of the economy

Microfinance Bank: A company licenced by CBN to render simple, flexible and sustainable financial services to the active poor and low income class

Social Intermediation: The social aspect of microfinance services to the target clients such as group formation, capacity building on financial literacy and managerial skills.

Tax Incentive: Deliberate reduction or elimination of tax liability by government to boost investments and growth in some identified sectors of the economy.

\subsection{The Meaning of Taxation}

\section{Literature Review}

Tax is a compulsory levy imposed by the government (federal, state or local) on individuals, groups of individuals, corporate residents and other legal entities. The assessee is under every obligation to pay the assessed amounts, since default or evasion attracts legal sanctions. Assessment of tax is based on the legal description of the object of taxation, say income, which is called the tax base.

Taxes are very important sources of government revenue as well as a vital instrument of resource transfer from the private to the public sector of the economy. Taxation is said to "serve all the five functions of government, namely; allocative, distributive, regulative, coordination and stabilization functions" (Agiobenebo, Onuchuku, and Ajie, 2003 in Ezirim, 2005:508). The allocative function of taxes includes both the allocation between public and private uses of resources; and allocation between investment and consumption. The distribution function of taxes derives on their ability to correct inequality or bridge existing resource imbalance in the economy. Progressive taxation, for instance, aims at making the rich pay more or surrender more income than the poor. Taxes on wealth aim also at reducing the richpoor gap. The extent of successful distribution or redistribution is a function of the tax rates and their progressiveness. There is no doubt nonetheless that taxation reduces the gap between the absolute levels of income between the high and low-income groups. Governments use taxes to influence and control economic behaviour where the type of tax used bears on the regulatory objective.

Taxation has been used by governments for social control where harmful commodities have had their consumption restricted due to prohibitive prices occasioned by taxes. Taxation equally serves as a tool 
of economic stabilization. For instance, taxes that restrict purchasing power have been employed in the management of aggregate demand. Negative taxation (subsidies) can also be used to stimulate aggregate demand and hence production.

Taxes are used when the economy wants to maintain or achieve sustained rate of economic growth, price stability, full employment, and balance of payment viability. The particular objective(s) given more emphasis dictates the rate and direction of taxation. The coordinating function of taxes identifies itself with the need to balance conflicting choices and policy objectives. To Agiobenebo et al (2003) in Ezirim (2005: 509) "it deals with the central management function of an economy involving the management of the interaction among the other four functions with a corrective role for taxation in the area of institutional deficiencies and missing links, if any".

\subsection{The Principles (Canons) Of Taxation}

According to Anyafo (1996:57-60), by principles of taxation we mean the appropriate criteria to be applied in the development and evaluation of the tax structure. Such principles are essentially an application of some concepts derived from welfare economics. In order to achieve the broader objectives of social justice, the tax system of a country should be based on sound principles. The key principles or cnons are:

\subsubsection{The Canon of Equity}

Adam Smith advocated that the amounts payable by taxpayers should be equal, by which he meant proportional to income. Only when a tax is based on the tax payer's ability to pay can it be considered equitable or just. Sometimes this canon of taxation is interpreted to imply proportional taxation. However, the proportional principle is not regarded today as the most equitable, since the payment of $\$ 150$ by a person with $\$ 1,500$ income per annum is a heavier burden than the payment of $\$ 1,500$ by a person with an annual income of $\$ 15,000$. To be equitable, the tax burden should be spread among the people according to their financial muscle. In other words, the rich should contribute at a higher rate than the poor. This sounds more progressive.

\subsubsection{The Canon of Certainty}

The principle of taxation expressed in this regard is that the taxpayers ought to be aware of the exact amount of tax they are expected to pay as well as the time and method of payment. If "certainty of tax" is doubtful it will lead to insolence and corruption on the part of the tax officials. Certainty of tax purges the public revenue system of arbitrariness. If a tax is that the taxpayers have to consult the revenue officials for interpretation of its implication then taxpayers are merely at the mercy of inland revenue officials. This will lead to all sorts of abuse of office; bribery, corruption and nepotism. On the part of the government, the principle of certainty implies that it would be easier to predict with greater accuracy the amount of tax-revenue for budgetary purposes.

\subsubsection{The Canon Of Convenience}

It is advocated under the canon of convenience that taxes should be conceived in such a way that the manner and time of payment should be suitable to the tax payers. To ensure that the manner and time of payment of a tax is free from difficulty, it is necessary to relate the ways in which the taxpayers receive and spend their incomes with the collection of the tax. This provides the rationale for the Pay as You Earn (PAYE) system of tax collection. PAYE is a system of paying income tax where the tax payable is deducted at source from current earnings, weekly or monthly, and the employers being made to account directly to the relevant tax authority. When PAYE was first introduced in England in 1943 the amount of tax depended on earnings during the previous financial year, the amount being deducted in equal installments, but in 1945 deductions were made dependent on earnings during the current financial year. Employers are issued tax tables to guide the amount to be deducted (Hanson, 1974).

\subsubsection{The Canon Of Economy}

This principles of Taxation requires that taxes should not be imposed if their cost of collection was excessive. Two issues arise in this regard. In the first place, a tax can be considered economical if the cost of collection is not excessive. On the other hand, if the cost of collection takes a large part of the tax collected, the tax is not economical. There is no wisdom in killing a fly with a sledge hammer, thus, if the yield from a tax is $\$ 25$ million and the cost of collection is $\$ 24$ million; then the tax is quite uneconomical. The second issue with regard to the economy of taxation is that a tax should be free from transmitting a counter-productive repercussion on capital formation, employment, savings and production. For this reason, taxes on imported luxury goods are economical because they not only boost government 
revenue but also discourage expenditure on non-essential and less productive items which may result in higher social costs.

On the other hand, taxes on raw materials, spare parts and baby foods would be uneconomical in that such taxes would discourage production as well as increase the cost of production and people's suffering.

\subsubsection{The Canon Of Simplicity}

This canon of taxation requires that the tax system should be sufficiently simple for the people to understand. There should be no hidden agenda in a tax law. Ambiguities should be avoided. A properly understood tax system eliminates the chances of corruption and oppression by tax officials.

\subsubsection{The Canon Of Productivity}

Also referred to as the principle of fiscal adequacy, this canon advocates that the proceeds, or yield from a tax should be adequate to cover government expenditure. An income tax system which targets only the high income group and the rich minority may not yield enough revenue if altogether all the other income groups are exempted. A productive tax enhances rather than inhibits the productive capacity of the economy, thus, if the entrepreneurs are excessively taxed, this can be counter-productive since such a tax would constitute a disincentive to investment. An unproductive tax can engender capital fight from a country. Another point is that a few taxes with high yield are better in terms of productivity than a multiplicity of taxes with low yields.

\subsubsection{The Canon Of Flexibility}

Under the canon of flexibility, it is recognized that instead of a rigid tax system it is preferable to have tax system that is responsive to changing realities. Such an adjustable tax system would allow any tax found to be obsolete to be scraped and substituted with an innovative and meaningful alternative. Nigeria recently scrapped the sale tax and substituted with the Value Added Tax.

\subsubsection{The Canon Of Impartiality}

A taxation principle established under the canon of impartiality is that a tax should not discriminate between tax payers under similar circumstances. An impartial tax system ensures that all persons similarly placed pay the same tax. This principle applies to both direct and indirect taxes. For example, all tax payers who have dependent relatives are expected to enjoy the applicable relief to the limit allowed. In the case of indirect taxes, a selective tax on alcoholic liquor falls on all alcohol consumers to the limit of their appetite and resources while non-consumers of alcohol are free.

However, the tax laws allow for discriminatory taxation or discriminating duty under certain circumstances. Products of certain matured industries can be targets of discriminatory taxation in order to enable pioneer and infant industries to compete more favourably against them.

Suggestions have for example, been made that oil should in UK be taxed in order to encourage the use of coal for power and heating. Discriminating duty refers to an import duty which varies according to the country of origin of the imported goods such as preferential duties imposed by Nigeria in favour of ECOWAS countries.

Stephen and Osagie (1985:186) points out that in practice governments do not seem to be doing much to conform with all the canons when tax systems are formulated. The reason according to them, is because of the complex nature of modern economies which makes it impossible to introduce only taxes that would satisfy all the canons. Besides, the majority view is that it is enough if the system as a whole conforms to some of the important canons.

\subsection{Theories Of Taxation \\ 2.3.1 Faculty Theory}

This is also known as "Ability-to-Pay" theory of taxation, it states that everyone should be taxed according to his ability to pay. The problem with this theory is that it is not easy to measure with accuracy and fairness the ability to pay of people even in superficially similar circumstances (Hanson: 1974). The theory that taxes should be levied in accordance with the taxpayer's ability to pay is often considered the basic criterion of justice taxation. It suggests that those who have equal ability to pay should shoulder the same burden and those who posses greater financial ability should bear heavier tax burden. Horizontal equity of taxation implies equal tax burden for those with the same income. Vertical equity of taxation implies different tax burden for those with different abilities to pay. 


\subsubsection{Benefit Theory of Taxation}

The benefit theory of taxation, according to Browning and Browning (1979) implies a specific method for distributing the tax burden; taxes should be allocated on the basis of benefits received from government expenditures. If it can be shown that benefits increase faster than income, then a compelling case for progressive taxes can be made. The value of some benefits increases with income; for example, police and fire service protection are probably more important to wealthier people with more property to protect. It is unlikely; however, that this will be true for all government provided goods and services.

The great advantage of the benefit principles is that it emphasizes the essential two-sidedness of government tax-expenditure decisions. If people do not receive benefits commensurate with their tax burden, then perhaps the expenditure should not be undertaken at all. However, there is no way of determining the benefits to specific people from expenditures on public goods such as national defence. In addition, there is the question of how to redistribute income under such a system - if low income group were taxed on the basis of benefits received from a policy of income redistribution, the effect of such policies would be negated. For these reasons, the notion that the basis of progressive taxation be in accordance with benefits received is unpopular. And in any case, by definition, taxation is a payment conferring no direct and specific quid pro quo to the payer.

\subsubsection{Taxable Capacity Theory}

This theory is an expression of the extent to which a people can be taxed. Hanson (1974) points out that it is very difficult to decide what is the taxable capacity of a people, for it depends to a considerable extent on what the state does with the revenue from the taxes. The limit of taxable capacity might be considered to be the point beyond which the additional taxation would produce economically harmful results (such as a fall in the national income) that out-weigh the gain from the service provided by the state from this additional taxation.

Whereas the state uses taxes to provide services for the community it is really returning to taxpayers the money they have paid in taxes though, depending on his income, the gain to the taxpayer may be more or less than his loss of satisfaction resulting from the payment of taxes.

Dalton (1964) took a hard look at the theory of taxable capacity, distinguishing what he termed the "absolute taxable capacity of single community" and the "relative taxable capacity of two or more communities". After the analysis, he concluded that "relative taxable capacity is a reality, which can, however, be equally well expressed in other terms, while absolute taxable capacity is a myth. In the interest of clear thinking, Dr. Hugh Dalton however advised that it would be well that the phrase "taxable capacity" should be banished from all serious discussions of public finance.

\subsubsection{Single Tax System Theory}

Single tax system theory advocates that the income taxes can be more equitably assessed on individuals than other taxes. A weakness of this theory emanates from the fact that to raise the single tax would have to be extremely high and would therefore have a serious distinctive effect on the desire to work and as a result it would have an adverse effect on the size of the national income.

The physiocrats in Finance proposed a single tax on the economic rent of land because they thought that this was where all taxes ultimately fell, and it would, therefore, save trouble and misunderstanding to put them there straight away. But these ideas involved a false theory of incidence.

Another weakness of the single tax system theory as advocated by the physiocrats is that it would lead to a very bad distribution of the burden of taxation. For a millionaire who owned no land would pay no taxes while a poor man who had invested all his savings in the purchase of his house might pay in taxation in respect of the land on which it stood a considerable proportion of his income. A single tax on land, thus, has no relation to individual's ability to pay.

Tax evasion may be comparatively easy under a single tax unlike in a multi-tax system where the check and counter-check provided will more readily expose an evader. Though a multi-tax system is generally preferable to a single tax system, too great a multiplicity is not desirable.

\subsection{Direct Tax Assortment Vis-À-Vis Nigeria Experience}

Specifically, the following assortment of direct taxes are recognized in most developing countries: Personal Income Tax; Company Profit Tax; Capital Gains Tax; Capital Transfer Tax, Petroleum Profit Tax (for petroleum producing countries); others (possibly related to other natural resources and profits accruing from exploiting them). A brief explanation of the main import or primary significance of each kind of direct tax follows. 
a. Personal Income Tax: Personal income tax is a tax on all types of income: rent, wages, interest and profit. It is one of the oldest forms of tax.

The term earned income is used by the Inland or Internal Revenue authorities to mean income derived from paid employment, whether as an employee or as a self-employed person as distinct from unearned income which, for tax purposes, is income derived from interest and dividends. Most Tax Authorities tax earned income more leniently than investment income. However, it may be argued that apart from gift and other windfall, all income is earned in that it is payment for economic services to production and distribution. A person who hold Government sock is paid interest for this services of lending to the Government. In economics, unearned income comprises only pure economic rent and the surplus profits of the monopolist.

With respect to personal income tax, there was no uniformity in Nigeria before $1^{\text {st }}$ April 1974 as to the rates because the jurisdiction over personal income taxation was devolved first on the regional governments and later on the emergent state governments under Nigeria's model of fiscal federalism. However, on the strength of Income Management (Uniform Taxation Provision etc) Act 1975 No 7 which became effective from $1^{\text {st }}$ April 1974, an amendment was effected on the Income Tax Management Act 1961 No 21 and the Armed Forces and Other Persons (Special Provision) Act 1972 No 51 to provide for uniformity in the taxation of the income of individuals throughout the country.

Uniform income tax rates were also prescribed but State Governments were empowered to retain any existing capitation, community development, education, poll or other general tax or levy, and to vary them.

b. Company Profit Tax: Company tax also known as, corporation tax (in UK and elsewhere) is a tax on the profits made by companies. Theoretical economists generally condemn taxes on profits on the ground that they check enterprise, being a penalty for success with no compensation for failure. Since Britain influence Nigeria by virtue of colonialism, having an idea of what happened in UK on the issue at hand, help to place Nigeria. In both World Wars, excess profits taxes, were imposed in Britain and in these circumstances there is justification for such taxes, through an equitable assessment of what is "excess" I really impossible. The income tax equivalent of the so called "excess profit tax" is the surtax or super tax which as the name implies is a steeply progressive income tax imposed on high income groups over and above the normal income tax.

During the 1945-65 periods varying rates of profits tax were levied in UK, justifiable perhaps on the ground that since the Government, has accepted responsibility for full employment, conditions favouring the earning of profit have been provided by the Government itself. Sometimes discrimination is made in favour of undistributed profits in order to encourage firms to plough back profit into their business.

In 1963 a Corporation Tax was introduced in the UK to replace profit tax and income tax on companies. Under this system distributable profits were taxed twice, the company paying Corporation Tax and the shareholders paying income tax. From 1973 this was eliminated by the introduction of the imputation system. Companies will make advance payments of Corporation Tax equal to $3 / 7^{\text {th }}$ of the dividends, this to be offset against their total tax for the period. Shareholders receive a dividend and a tax credit equal to the standard rate of income tax (Hanson, 1974; Prest, 1975:368-371; Williams, 1975:348). There was no company profits taxation in Nigeria before 1937 Income Tax Ordinance No. 23 and all previous Ordinances had no provision for company profits tax. In 1937 that ordinance was amended and frames generally on British lines, except that the Nigerian Ordinance did not provide for company taxation. It was only in 1939 on the strength of Companies Income Tax Ordinance No.14 of 1939 that, for the first time, Government introduced a tax of 2 shillings and 6 pence in the 1 on company profits.

The Governor of Nigeria commenting on the new tax in his address to the Legislative Council said"..... A tax on the income of companies is already taken in most countries and the introduction of such a tax on orthodox lines needs no excuse. On the contrary, it appears to me a matter for regret that such a tax was not imposed years ago" (Ekundare, 1970). The Income Tax Ordinance 1940 No. 3 made all companies pay a flat rate of 5 shillings in the as the company profits tax. The 1940 Ordinance was replaced by the Income Tax Ordinance 1943 No. 29 and subsequently amended by the Income Tax Ordinance 1944 No. 39 and 1945 No. 23. the situation did not significantly change until after Nigeria's independence in 1960 when in 1961 the Government for the first time, came up with a legislation designed purely for taxation of company profits in Nigeria, that is, the Companies Income Tax Act 1961 No. 22. This Act was in force as amended subsequently until repealed and replaced by the companies Income Tax Act 1979 No. 28 with effect from April.

Company taxes are designed to collect revenue from a firm's economic profits. In practice, the tax base is net accounting profits: gross revenue less operating costs and capital adjustments. Often a single statutory rate is used and is usually most desirable, particularly when there are administrative constraints. The statutory rate of the company tax is often a poor indicator of its effects on revenue or investment behaviour. Rates apply to financial income not economic income; inflation; for instance, drives the two apart. For policy, therefore effective tax rates are more important, the average effective tax rate (AETR) is the ratio of total revenues collected through the company income tax to the company's economic profits. For revenue purposes this rate 
should be high. By contrasts, the marginal effective tax rate (METR) measures the effect of taxes on investors' rate of return for an incremental addition to their activities. To avoid interfering with investment decisions, the METR should be low. The main tasks of company tax design should be to achieve a high AETR while keeping the METR low or preferably zero, and to avoid large variations in METRs across different types of investment (World Development Report, 1988: 92-93).

Super tax on company was introduced in Nigeria during the Nigerian Civil War (1967-70) under the Super Tax Decree 1967 No. 46 which empowered the Federal Board of Inland Revenue to prepare in respect of each year of assessment lists of companies liable to super tax. The Super Tax (Amendment) (No. 2) Decree 1971 No. 12 amended the Super Tax Decree 1967 by introducing a reduced rate of Super tax which applied with effect from $1^{\text {st }}$ January 1971 . However super tax was abolished under the Finance (Miscellaneous) (Taxation Provisions) Decree 1972 No. 47 with effect from $1^{\text {st }}$ April 1972.

Yield from company taxation in Nigeria has been considerably low due largely to the generous tax concessions, rebates and tax-holidays allowed to newly established companies. Other factors responsible for low yield include tax evasion and tax avoidance. Differences between METRs and statutory rates arise from provisions that allow the recouping of invested capital, deduction of interest on investment debt, corrections for inflation, etc.

c. Petroleum Profits Tax: A little background is necessary about Nigeria's petroleum endowment in order to justify the necessity for a pride of place to the taxation of petroleum profits. Though the first commercial production of oil in the world had taken place in Romania and the United State in the 1850s, commercial discovery of oil in Nigeria was not until the 1950s. The Shell-BP, however, had earlier started some exploration work shortly before the Second World War. Nigeria is the largest producer and exporter of crude petroleum in Africa south of the Sahara. It is a member of the Organization of Petroleum Exporting Countries (OPEC). Nigeria's oil has technical and commercial advantages compared with some other major oil-exporting countries. Its quality varies between light crude of $45^{\circ} \mathrm{API}$ and heavy crude of $21^{\circ} \mathrm{API}$, with weighted average of $32^{0} \mathrm{API}$. This average yields a very good quality of light crude preferred by petroleum refiners, especially when coupled with the fact that the Nigerian oil has an incredibly low sulphur content averaging only $0.2 \%$. Of all other major producers, only Libya and Indonesia have qualities which may be regarded as comparable.

Petroleum Profit Tax is singled out for special attention because of the significance of oil in Nigeria's public revenue performance. The Petroleum Profits Tax Act 1959 No. 15 imposes with effect from $1^{\text {st }}$ January 1959, a tax upon profits from the winning of petroleum in Nigeria.

Nigeria was not politically independent when commercial production of oil started, and for about a decade after its independence it did not have any positive or coherent oil policy. The general posture was therefore one of great caution and a broad bias for measure to stimulate exploration and development by the foreign oil companies. Various incentives were given to these companies: full expansion of exploration costs, rapid amortization of capitalized and capital costs (within 5 years), a highly favourably investment tax credit system and progressive increase in the margins per barrel allowed companies in calculating their profit.

\subsection{The Concept of Tax Incentives}

As posited by Adedokun (2001:142) Tax incentive is "the reduction in the effective tax burden on the favoured economic activity as against that currently imposed upon it, with the hope that reduction in government revenue would bring an expected expansion of the national economy and ultimately bring a relative increase in total revenue from such broadened economic basis".

Also Tax incentives according to Gberegbe (2007: 18) are those devices used by the government to encourage investments. They are essentially designed to promote industrialization especially in the area of manufacturing activities. Examples are accelerated depreciation, tax holidays and import duty relief.

\subsubsection{Tax Incentives for Agribusiness in Nigeria}

As stated in Ironkwe (2011:138-140), section 9 (8a) of CITA (2007) defines an agricultural trade or business to mean any trade or business connected with:

a. The establishment or management of plantations for the production of rubber, oil palm, cocoa, coffee, tea and similar crops.

b. The cultivation or production of cereal crops, tuber, fruits of all kinds, cotton, beans, groundnuts, sheanuts, beniseed, pineapples, bananas and plantains.

c. Animal husbandry, that is, to say, poultry, piggery, cattle rearing and fish farming.

The tax incentives to agribusinesses as provided by section 9 are:

i) Loan interest earned by banks on lending for agricultural business: The government in a bid to encourage agricultural production, with effect from 1991 exempted from tax interest earned by banks on 
loans granted for agricultural business. However the government expects that the loan would have the following features

- $\quad$ Moratorium period is not less than 18 months;

- Rate of interest is not more than the base lending rate of the bank granting the loan. Base lending rate is the average cost of funds to a bank.

ii) The rate of initial allowance on plant and Machinery used in agricultural production is now 95\% (w.e.f 1/1/96) up from $25 \%$. The $5 \%$ balance is retained in the books until the asset is sold or otherwise disposed of. Similarly, annual allowance rate on Ranching and Plantation had been increased to $50 \%$ from $15 \%$.

iii) From 1/1/96, Plantation equipment expenditure now attracts $95 \%$ initial allowance as against the former $20 \%$.

iv) Small agricultural businesses (those with turnover of less than N1 Million) in the year of assessment are charged to the lower concessional rate of $20 \%$ for the first five years of their operation.

v) Loss Relief: A loss incurred by a business in agricultural production can be carried forward for an indefinite number of years to be set-off against future profits in the same line of business. In all other companies (other than agriculture), the maximum number of years to carry forward a loss is four years after which the loss would lapse.

\subsubsection{Tax Incentives for Foreign Investors in Nigeria}

The Chairman of Federal Inland Revenue Service, Ifueko Okauru (FCA) presented a paper at the Nigeria investors Business Forum at Berne Switzerland on $20^{\text {th }}$ and $21^{\text {st }}$ November 2009 which gave some reasonable insights into tax incentives as follows;

\section{a. Why Tax Incentives?}

Tax incentives are special arrangements in the tax laws to:

i) Attract, retain or increase investment in a particular sector

ii) Stimulate growth specific areas

iii) Assist companies or individuals carrying on identified activities

iv) Underlying basis is to ensure overall growth of the Nigeria economy and even development of all sectors

b. Current Policy of Nigerian Government is to ensure:

i)Incentives are sector based and not granted arbitrarily

ii)Benefit to the Nigeria economy exceeds the cost of taxes forgone

iii)Incentives are reviewed regularly to confirm if they are serving the expected purpose

iv)Foreign investors enjoying incentives are expected to voluntarily plough back into the Nigeria economy

c. Tax Incentives in Nigeria:

Tax laws provide various incentives to companies carrying on business in Nigeria. Incentives may be granted on industry basis or on tax type and may include;

i)Exemption from payment of taxes

ii)Reduction in rate of tax to be paid

iii)Grant of allowances and deductions from profits subject to tax etc

iv)President has broad powers to grant tax incentives to any company or individual

d. Under the Industrial Development Act:

Pioneer Status is granted to qualifying companies and/or products and services resulting in 3-5 years tax holidays. Qualifying industries include;

i) Mining

ii) Manufacture of cement, glass and glassware, lime from limestone, ceramic products, rubber, leather textile etc

iii) Areas of industry that are of economic benefit to the country

e. Pioneer Status:

Granted to companies in certain industries where it is deemed that;

i) The industry is not carried out on a scale suitable to Nigeria's economic requirements

ii) It is in public interest to do so

iii) Tax exemption for a three year period in the first instance and a maximum of five years in total

iv) Tax free dividends during pioneer period

v) Carry forward of losses made and capital allowances (on assets) incurred during the pioneer period

f. Under the Companies Income Tax Act:

i) Loans granted to Nigerian companies may be exempt from tax, where they meet prescribed criteria

ii) Dividends received from Nigeria are exempt from tax, other than withholding tax deducted at source

iii) Profits of shipping and airline companies subject to tax in Nigeria is restricted to activity carried out in Nigeria 
iv) Dividends interest, rent or royalty earned by companies outside Nigeria and brought in through specified channels are exempt from tax

v) Interest earned by a foreign company on its bank deposits in Nigerian are exempt from tax

vi) Nigeria companies with a minimum of $25 \%$ foreign equity and within their first four years of operation are exempt from payment of minimum tax

vii) Incentives for downstream gas utilization projects

viii) Exemption from taxes for specified period tax free dividends etc

g. Incentives under the Personal Income Tax Act

i) Non-Nigerian employees of foreign companies in Nigeria may be exempt from tax in Nigeria, where

$>$ They spend a cumulative period of less than 183

Days in Nigeria during a 12 months period, and

$>$ Their income is subject to tax in their home country

ii) The Minister of Finance has wide powers to grant exemptions to any person based on a treaty entered into with Nigeria

h. Incentives Under the Capital Gains Tax Act

Foreign companies carrying on business in Nigeria are exempted from capital gains tax on disposal of assets, except such proceeds are brought into Nigeria

i. Incentives under the petroleum profits Tax Act

i) Expenses incurred outside Nigeria which are wholly, exclusively and necessarily incurred for the Nigerian operations are allowed as deductions against the profits of the Nigerian company (this may include parent company expenses incurred in respect of the Nigerian company)

ii) Interest on inter-company loans obtained under open market terms are allowed as deductions

j. Incentives under the Value Added Tax Act

i) Import of several items exempted from value added tax

ii) Exported goods and services also exempted from value added tax

iii) Exemption of value added tax on the services of community banks

k. Import and Export Duty Exemptions and Reductions

i) Import and export duty exemptions and reductions are available for several items

ii) List of exempt items and rates is reviewed annually based on economic considerations and developments in the Nigeria economy

1. Incentives under the Tax free Zones and Export Processing Zones

i) There are laws creating tax free Zones and export Zones, which exempt companies operating in those areas from tax obligations in Nigeria for operations carried out in the Zones

ii) Companies are required to register before enjoying the benefits and all activities must be performed exclusively within the Zones - activities outside the Zones will be subject to tax

iii) Tax free status is continuous as long as activities are restricted to the Zones - Government may however review the status of the zones based on economic considerations

\section{m. Nigeria's Double Tax Treaty Network}

This offers significant incentives to investors and there is considerable room for further expansion subject to development of a clear tax treaty strategy. Nigeria has existing treaties with United Kingdom, Canada, Belgium, France, Romania, Netherlands, Pakistan, South Africa, China, South Korea, Spain, Sweden and Russia.

\subsection{The Concept of Microfinance}

As stated in CBN Microfinance Policy, Regulatory and Supervisory frame work (2005: 5-6), Microfinance is about providing financial services to the poor who are traditionally not served by the conventional financial institutions. Robust economic growth cannot be achieved without putting in place well focused programmes to reduce poverty through empowering the people by increasing their access to factors of production, especially credit. The latent capacity of the poor for entrepreneurship is significantly enhanced through the provision of microfinance services to enable them engage in economic activities and be more selfreliant; increase employment opportunities, enhance household income, and create wealth. Three features distinguish microfinance from other formal financial products. These are: (i) the smallness of loans advanced and or savings collected; (ii) the absence of asset-based collateral, and (iii) simplicity of operations.

In Nigeria, the formal financial system provides services to about $35 \%$ of the economically active population while the remaining $65 \%$ are excluded from access to financial services. This $65 \%$ are often served by the informal financial sector, through the Co-operative Societies, Non-Governmental Organization (NGO) Microfinance Institutions, Moneylenders, Friends, Relatives, and Credit Unions.

According to Marguerite (2001) in Nwiyordee (2012:14-23) Microfinance refers to small-scale financial services-primarily credit and savings- provided to people who farm or fish or herd; who operate small enterprises or micro enterprises where goods are produced, recycled, repaired, or sold; who provide services; 
who work for wages or commissions; who gain income from renting out small amounts of land, vehicles, draft animals, or machinery and tools; and to other individuals and groups at the local levels of developing countries, both rural and urban. Many such households have multiple sources of income. Savings services allow savers to store excess liquidity for future use and to obtain returns on their investments. Credit services enable the use of anticipated income for current investment or consumption. Overall, microfinance services can help low-income people reduce risk, improve management, rise productivity, obtain higher returns on investments, increase their incomes, and improve the quality of their lives and those of their dependants.

Such services are rarely accessible through the formal financial sector, however, credit is widely available from informal commercial moneylenders but typically, as will be documented, at very high cost to the borrowers-especially poor borrowers. Banks generally assume that providing small loans and deposit services would be unprofitable. It is widely believed though wrongly that the cost of delivering small- scale financial services at the local level is too high for unsubsidized institutions and that the informal financial market satisfies demand. NGOs and other nonblank financial institutions have led the way in developing appropriate credit methodologies for low-income borrowers. But with few exceptions, these institutions operate only on a very small scale.

The problem is exacerbated by the limited influence of the poor people who require microfinance. They are usually unable to inform formal markets about their creditworthiness or about their demand for savings services and loans. Accordingly, services are not provided. Those who hold the power do not understand the demand; those who understand the demand do not hold the power.

There are differences among countries and regions in the availability of microfinance services and in the level of unmet demand for these services. There are also differences in demand among small businesses, micro enterprises, farmers, labourers, low-income salaried employees, and others. Common to nearly all parts of the developing world, however, is a lack of commercial microfinance institutions- a shortcoming that unnecessarily limits the options and lowers the financial security of poor people throughout the world.

The foregoing pattern is changing; the microfinance revolution is emerging in many countries around the world. As it is used here, this term refers to the large-scale, profitable provision of microfinance services small savings and loans-to economically active poor people by sustainable financial institutions. These services are provided by competing institutions at the local level -near the homes and workplaces of the clients-in both rural and urban areas. Financial services delivered at the local level refer to those provided to people living in villages and other types of rural settlements and to people living in low-income neighborhoods in semi urban or urban areas. Large scale as used here means coverage by multiple institutions of millions of client; or, for small countries or middle - and high-income countries with low demand, outreach to a significant portion of the microfinance market. Profitability means covering all costs and risks without subsidy and returning a profit to the institution.

In aggregate, commercial microfinance institutions can provide outreach to a significant segment of their country's poor households. In a few countries this had already occurred; in others it is at various stages of progress.

\subsection{The Nature of Micro Financing}

According to Osuji (2005), Micro financing is the provision of both credit and savings services to lowincome clients. Many microfinance institutions offer other services, like socially organizing the poor, their education and training. These are social intermediation roles. It differs from micro credit in that it offers more than loans. Micro credit is the provision of small loans, usually to the poor while microfinance embraces both small loans and other services.

Microfinancing has been described as the provision of financial services to low income or poor people including the self employed (Ledgerwood, 1998:1). It refers generally to the provision of small-scale financial services. (Gulli, 1998:1), Micro financing has also been described as the most realistic and vital channel for financing the poor but as usual with many problems. This is because doubts arise on many occasions as to who the poor really are.

There are also the differences in the levels of poverty. This is not unexpected because poverty has its own dimensions of relativity. In this regard, there are those how poor are only relatively in that they lack some basic things required for comfortable living. However, there are also those in abject poverty and who practically lack all things except life. Poverty is a state of lack and deprivation and micro financing is meant to alleviate it.

It is usual to find Microfinance Institutions (MFLs) in the form of Non-governmental Organizations (NGOs) but they also exist in the form of savings and loans associations, credit unions, finance companies and government departments. These institutions all focus on the provision of funds for individuals who may use such funds as initial or additional capital and other requirements of small business units. While recognizing the place of other factors of production, it is now accepted that capital is the most important (UNDP, 1997:2). 
It is only with capital that we can transform our creativity and drive it into material action. There is no shortage of dreamers in the world but dreams will not amount to much until we transform and put them to work. The estimate of economically active people who work for themselves or engage in various small enterprises and sole proprietorships, generally known as micro enterprises, around the world has been put at about 500 million (Women's world banking, 1995:1). These include weavers, blacksmith's potters, mechanics, neighborhood hairdressers, metalworking shops, street vendors and tiny retail shops displaying a variety of items. These people require funding not only kick-start their dreams but also to drive such dreams.

A large percentage of these people are women for which self-employment is second nature and main sources of livelihood. For a majority of them, financial resources are very hard to come by, including a safe place to keep their little savings. In general therefore, micro financing, unlike micro credit which is the provision of small loans only, encompasses the following activities:

(a) Loan Services

(i) Provision of small loans usually as working capital

(ii) Lending small amounts on the basis of character or guarantee rather than on collateral (making loans based on collateral substitutes.)

(iii) Making loans on the basis of reduced and simple documentation, typically a one-page document; and

iv) Affording small borrowers access to repeat and larger loans, based on good repayment record.

(b) Savings Services

(i) Providing timely and flexible savings facilities for very small savers; and

(ii) Creating opportunities for the poor to save out of their meager incomes.

(c) Other Services

Some microfinance institutions (MFIs) provide services other than financial services including insurance, training, marketing skills and literacy training programmers, along with financial services. These services are however not normally included in the concept of micro financing, even though it is now the trend that such services form part of the package offered in such institutions.

Accordingly, micro financing includes both lending and savings services targeted specifically at the small entrepreneurs or individuals to support their business operations. It includes micro credit which is essentially the lending services component of micro financing.

\subsection{Objectives of the Microfinance Institutions}

Selecting a target market depends on the objectives of the microfinance service provider and the perceived demand for financial services. In any country there are un-served or underserved enterprises and households, ranging from the ultra-poor, who may not be economically active, to small growing enterprises that provide employment in their communities. This range or continuum constitutes the demand side for microfinance services. Often the supply side does not offer a corresponding continuum of services. MFIs need to supply services that fill the gaps and integrate the un-served groups into the market.

The goal of MFls as development organizations is to service the financial needs of un-served or underserved markets as a means of meeting development objectives. These development objectives generally include one or more of the following.

i) To alleviate poverty

ii)To empower women or other disadvantaged population groups

iii)To create employment

iv)To help existing businesses grow or diversify their activities

v)To encourage the development of new businesses.

In a World Bank study of lending for small and micro enterprise projects, their objectives were most frequently cited (Webster, Riopelle, and Chidzero 1996):

vi) To create employment and income opportunities through the creation and expansion of micro enterprises

vii) To increase the productivity and incomes of vulnerable groups. Especially women and the poor

viii) To reduce rural families/ dependence on drought-prone crops through diversification of their income generating activities.

\subsection{Microfinance and Economic Development}

According to Ehigiamuse (2008), the underlying assumption of microfinance for development is that availability of capital is critical to the effort of enhancing income-earning capability of the poor. It is assumed that the poor know what to do to enhance their economic condition and that they remain poor because they operate from a slim economic base which can be strengthened by borrowing on affordable terms.

The rapid spread of microfinance in developing countries is attributed to its capacity to impact positively on poverty. Professor Muhammed Yunus of the Grameen Bank calls it "development from bottom". 
Most development initiatives in agriculture, health and female empowerment enhance their impact with the integration of credit programme. The improving condition of living in Bangladesh is a good example of how to develop with small loans. The South East Asian nation was in mid-1970s branded a 'basket case' by Henry Kissinger, a US Secretary of state, on accounts of the action's hopeless development prospects. Small loan are effective weapons for addressing mass poverty.

Impact of microfinance could be addressed to personal household as well as national dimension. It has been demonstrated that little loans availed much. On a general note, injection of new funds on appropriate conditions into small business take them from the vicious cycle of small investment little returns small investment, to the virtuous cycle of prosperity of little capita-injection of funds (credit) greater output, greater investment.

With financial services, poor households have recorded improvement in access to what matters most to them, that is, better nutrition and education for their children and medical services. An improvement in the economic condition of the poor especially women invariably reflects the nutritional status of members of their households. They are anxious about the future of their children. They want to put their children in school.

Microfinance has been demonstrated to have enormous capacity to boost economic development through support for micro, small and medium scale businesses. Current attention to microfinance as a strategy for economic development is driven by the emerging paradigm of "The fortune at the Bottom of the Pyramid," popularized by C.K. Parahalead.

Simply put, this paradigm refers to the enormous advantage of the large number of the poor in any economy and its implications for market and over-all economic development. It advocated for the integration of the poor with their number to THE MARKET at the most effective strategy to alleviate poverty without charity. In the process, the poor also make their contributions to National development. The vital link between the poor and the market or National economy is the microfinance institutions and banks. This is true of any economy including Nigeria.

The greatest constraint of small businesses and other actors in the informal sector is constrained access to affordable institutional credit. The existence of vibrant microfinance institutions would sufficiently address this challenge. China, India and other economics of Asia owe their vibrancy to viable small-scale industries/businesses adequately supported by viable and appropriate financial arrangements.

In spite of the dearth of statistics on volume of services provided by Microfinance institutions (MFls), it is evident that persons who ordinarily would not access institutional credit have done that through MFls. For example LAPO (Lift Above Poverty Organization) made the following disbursements in the past three years: 1.1billion (2005): N2.2billion (2007), 13.4b in 2009 and 31.58b in 2011 (Udeme Ekwere 2012). With the numerous microfinance banks, the volume of financial services to the "bottom of the pyramid" is expected to rise sharply. Agriculture has underperformed largely due to absence and inappropriate financial support approach. Microfinance institutions reach rural dwellers and women who ordinarily are locked out of conventional financing systems through innovative products and procedures. Therefore existence of viable microfinance banks/institutions with responsive products and services in rural communities would have impact on productivity of small scale farmers.

Beyond access to financial services, strict credit discipline of loan repayment and savings support clients to cultivate requisite discipline for business success. Economic actors hitherto outside the mainstream economy are integrated with attendant benefits for capital formation, improved productivity and overall national economic development. In a nation as Nigeria with exceptionally enterprising people, this benefit is enormous. By their large number and spread, small business development/support is a potent strategy for addressing mass unemployment. Microfinance creates self employment, which obviously is the most sustainable form of employment. Several beneficiaries start or manage their businesses no matter how small. In an economy where microfinance has been sufficiently developed, the informal sector depends mainly on microfinance institution for financial support. Micro, small and medium enterprises are regarded as the bedrock of the economy. It is evident that Nigeria is in need of entrepreneurial spirit and development. A prime mover of this development is the existence of appropriate financing arrangement.

\subsection{Maximizing The Gains Of Microfinance}

Ehigiamusoe further stressed that there are enormous opportunities for microfinance development in Nigeria. Here is a nation of huge market of exceptionally enterprising people. Microfinance seeks to create a positive face for the country beyond that of corruption. The face of microfinance has taken over from the images of corruption, cyclones and poverty in Bangladesh. It is helpful to add that these benefits would not come without the existence of microfinance sector with:

- Supportive enabling policy environment

- Sustainable refinancing

- Abundance of skilled operations 


\section{Enabling policy}

Regulation by statutory authorities has been acknowledged as a tool for developing the sector. However, the "rush to regulate" in some countries has replaced regulation with strangulation. It is gladdening that Nigeria has joined several developing nations to formulate a microfinance framework. This is commendable: however, for desired results, key provisions of the regulatory and supervisory guidelines should be subjected to periodic review in the face of emerging challenges. This is in view of the fact that there is hardly any perfect regulatory framework especially as the microfinance practice and sector are young and very dynamic.

\section{Sustainable refinancing}

Financing microfinance has gone through phases of funding. Donations and donor agencies dominated funding of non-profit microfinance practice of NGOs when emphasis was on feasibility of the practice. The desire to reach a large number of clients has rendered donations insufficient for the implementation of massive expansion plans. This has led to the involvement of private commercial institutions. Emerging regulatory environment across developing nations has also created platform for private capitalization.

In nations where microfinance has made significant contributions to national development, there exist strong and responsive refinancing institutions. This is so because there are still some concerns over the suitability of profit-driven investors to support microfinance institutions that support the poor.

Without any prejudice to the emerging refinancing arrangement, we wish to propose the following refinancing arrangement with the following features:

1) The establishment of a FUND to provide refinancing facility to fledging MFBs and poverty-focused microfinance institutions. While these institutions are desirable for their reach to rural areas, they will certainly be disadvantaged in competing for on-lending funds with participating commercial banks. Accessing government funds for these weak but relevant institutions will be an up-hill task.

2) Contributions to the fund should come from sources as varied as government, development agencies, private sources and even the microfinance institutions themselves. There are still developments agencies interested in microfinance development but are at lost on how to intervene in an environment of ultracommercialization.

3) The management of the fund should be as independent and professional as possible.

4) The fund, operationally, should have two (2) windows for funding: viz

i) Developing window through which funds should be channeled to fledging microfinance institutions and banks

ii) Commercial support window, which will support and noture microfinance institutions with loans on commercial interest rates.

\section{Skilled Operations}

Microfinance is no miniature commercial banking. The practice requires a unique set of skill and attitude. Emphasis should be on training operators for the sector. Attention should also be given to research and documentation. Institutions should go beyond considering elements of microfinance as novelty and appendix to business and banking courses. Microfinance institutions with competences should set up training and technical support centers. Skillful persons are required in critical areas as financial planning and treasury management, product development and improvement and information management. Capacity in non-financial issues as clients' engagement is also required. It is obvious that lack of money is not the only factor that constrains viability of micro and small businesses. Some forms of micro and small business management training are required to enable maximum utilization of borrowed funds to ensure impact and excellent repayment performance. For efficiency, such capacity enhancing interventions do not need to be elaborate; rather it should be incorporated into the financial service delivery procedures.

Microfinance practice is new. There are a lot of myths and misconceptions that need to be addressed for the development of the sector. One is that microfinance has been highly romanticized as instant and only cure for poverty. There is need for massive awareness creation about microfinance: what it is, what it is not, its gains and development potentials. The effort of the central bank of Nigeria in this regard is highly commendable.

\subsection{Microfinance as Instrument in Solving the Poverty Problems}

Ehigiamusoe (2000) further posited that Microfinance in principle, regards existence of poverty as arising from the denial of the poor of affordable financial services. In practice, it attempts at dismantling these constraints. The emergence of microfinance practice is therefore regarded as a response to the exclusion of the small entrepreneurs from formal financial system. Very few development practitioners doubt the effectiveness of microfinance as a development intervention strategy. Putting loans in the hands of the poor is premised on the assumption that meaningful development efforts must begin with the people especially the poor. It 
acknowledges the people's capacity to take responsibility for the improvement of their conditions. It recognizes that economic empowerment of the people is crucial to over-all development. Micro financial services represent one of the most effective tools of economic empowerment. The effectiveness of micro credit can be demonstrated thus:

A poor widow cultivates cassava; her output is constrained by the high cost of hired labour and dwindling soil fertility. Her condition of poverty is sustained. If she had access to affordable credit facility, she could increase output with hired labour, Purchase more cassava sticks for planting and fertilizers. With increased output, she breaks away from the vicious cycle of poverty and moves into the virtuous cycle of prosperity. Other factors as education and extension services are equally significant in bringing about desired prosperity. However, affordable credit remains the most effective escalator out of poverty. In the past two decades, several Micro Finance Institutions (MFIs) have emerged to create access to credit facilities for micro enterprises. Networks and support agencies have also emerged to strengthen service delivery mechanisms of these MFIs (Nwiyordee, 2012: 37 - 50)

\subsection{Microfinance Activities in Nigeria}

The practice of microfinance in Nigeria is culturally rooted and dates back several centuries $(\mathrm{CBN}$, 2005). The traditional microfinance institutions provide access to credit for the rural and urban, low-income earners. They are mainly of the informal Self Help Groups (SHGs) or Rotating Savings and Credit Associations (ROSCAs) types. Other providers of microfinance services include savings collectors and Co-operative Societies. The informal financial institutions generally have limited outreach due primarily to paucity of loan able funds.

In order to enhance the flow of financial services to Nigerian rural areas, Government has, in the past, initiated a series of publicly-financed micro/rural credit programmes and policies targeted at the poor. Notable among such programmes were the Rural Banking Programme, sectoral allocation of credits at concessionary interest rate, and the Agricultural Credit Guarantee Scheme (ACGS). Other institutional arrangements were the establishment of the Nigerian Agricultural and Co-operative Bank Limited (NACB), the National Directorate of Employment (NDE), the Nigerian Agricultural Insurance Corporation (NAIC), the Peoples Bank of Nigeria (PBN), the Community Banks (CBs), and the Family Economic Advancement Programme (FEAP).

In 2000, Government merged the NACB with the PBN and FEAP to form the Nigerian Agricultural Co-operative and Rural Development Bank Limited (NACRDB) to enhance the provision of finance to the agricultural sector. It also created the National Poverty Eradication Programme (NAPEP) with the mandate In December, 2005, the Nigerian government under President Olusegun Obasanjo launched the new microfinance policy to usher in Microfinance Banks.

\subsection{Microfinance Bank}

A microfinance bank (MFB), unless otherwise stated, shall be construed to mean any company licensed by the Central Bank of Nigeria to carry on the business of providing financial services such as saving and deposit, loans, domestic fund transfers, other financial and non-financial services to microfinance clients.

\subsection{Microfinance Banks Target Clients}

A microfinance bank target client shall include the economically active low-income earners, low income households the un-banked and under-served people, in particular, vulnerable groups such as women, physically challenged, youths, micro-entrepreneurs, informal sector operators, and subsistence farmers in urban and rural areas.

\subsection{Micro Enterprise}

A microenterprise is a business that operates with very small start-up capital. The management is often built around the sole owner or micro-entrepreneur. It provides employment for few people mainly the immediate family members and does not often require formal registration to start.

The management and accounting requirements are very simple and flexible. Generally, most microentrepreneurs work informally, without business licenses or formal records of their activities. The scope of economic activities of micro-enterprises typically includes primary production and crafts, value added processing, distributive trades and diverse services.

\subsection{Microfinance Loan}

A microfinance loan is granted to the operators of micro-enterprises, such as peasant farmers, artisans, fishermen, youths, women, senior citizens and non-salaried workers in the formal and informal sectors. The loans are usually unsecured, but typically granted on the basis of the applicant's character and the combined cash flow of the business and household. 
The tenor of microfinance loans is usually within 180 days (6 months). Tenors longer than six (6) months would be treated as special cases. In the case of agriculture, or projects with longer gestation period, however, a maximum tenor of twelve (12) months is permissible and in house microfinance, a longer tenure of twenty-four (24) months is permissible. In line with best practice, the maximum principal amount shall not exceed $\$ 500,000$ or one (1) per cent of the shareholders fund unimpaired by losses and/or as may be reviewed from time to time by the CBN. Microfinance loans may also require joint and several guarantees of one or more persons. The repayment may be on a daily, weekly, bi-monthly, monthly basis or in accordance with amortization schedule in the loan contract.

\subsection{Permissible And Prohibited Activities Of Microfinance Banks In Nigeria}

The Revised Microfinance Regulatory and Supervisory Guidelines (2012:9-11) states as follows;

\subsubsection{Permissible Activities}

An MFB shall be allowed to engage in the provision of the following services to its clients:

a. Acceptance of various types of deposits including savings, time target and demand from individuals, groups and associations; except public sector deposits;

b. Provision of credit to its customers, including formal and informal self-help groups individuals and associations;

c. Promotion and monitoring of loan usage among its customers by providing ancillary capacity building in areas such as record keeping and small business management;

d. Issuance of redeemable debentures to interested parties to raise funds from members of the public with the prior approval of the $\mathrm{CBN}$;

e. Collection of money or proceeds of banking instruments on behalf of its customers including clearing of cheques through correspondent banks;

f. Act as agent for the provision of mobile banking and micro insurance services to its clients.

g. Provision of payment services such as salary, gratuity, pension for employees of the various tiers of government;

h. Provision of loan disbursement services for the delivery of the credit programme of government, agencies, groups and individual for poverty alleviation on non-recourse basis;

i. Provision of ancillary banking services to its customers such as domestic remittance of funds and safe custody;

j. Maintenance and operation of various types of account with other banks in Nigeria;

k. Investment of its surplus funds in suitable instruments including placing such funds with correspondent banks and in Treasury Bills;

1. Pay and receive interest as my be agreed upon between the MFB and its clients in accordance with existing guidelines;

m. Operation of micro leasing facilities, microfinance related hire purchase and arrangement of consortium lending as well as supervision of credit schemes to ensure access of microfinance customers to inputs for their economic activities;

n. Receiving of refinancing or other funds from $\mathrm{CBN}$ and other sources, private or public, on terms mutually acceptable to both the provider of the funds and the recipient MFBs;

o. Provision of microfinance related guarantees for its customers to enable them have better access to credit and other resources;

p. Buying, selling and supplying industrial and agricultural inputs, livestock, machinery and industrial raw materials to low-income persons on credit and to act as agent for any association for the sale of such goods or livestock;

q. Investment in shares or equity of a body corporate, the objective of which is to provide microfinance services to low-income persons;

r. Investment in cottage industries and income generating projects for low-income persons as may be prescribed by the $\mathrm{CBN}$;

s. Provision of services and facilities to customers to hedge various risks relating to microfinance activities;

t. Provision of professional advice to low-income persons regarding investments in small business; rendering managerial, marketing, technical and administrative to customers and assisting them in obtaining services in such fields;

u. Mobilize and provide financial and technical assistance and training to microenterprises;

v. Provision of loans to microfinance clients for home improvement, housing microfinance and consumer credit; and

w. Performance of non-banking functions that relate to microfinance business development services such cooperatives and group formation activities, rural industrialization and other support needed by micro enterprises. 
Tax Incentives \& Microfinance Business In Nigeria: A Study Of Selected Microfinance Banks In ..

\subsubsection{Prohibited Activities}

a. Acceptance of public sector (government) deposits except for the permissible activities (g) and (h);

b. Foreign exchange transactions;

c. International commercial papers;

d. International corporate finance;

e. International electronic funds transfers;

f. Clearing house activities;

g. Collection of third party cheques and other instruments for the purpose of clearing through correspondent banks;

h. Dealing in land for speculative purposes;

i. Dealing in real estate except for its use as office accommodation;

j. Provision of any facility for speculative purposes;

k. Leasing, renting, and sale / purchase of any kind with its directors, officers, employees or persons who either individually or in concert with their family members and beneficiaries own five percent (5\%) or more of the equity of the MFB, without the prior approval in writing of the CBN; and

1. Financing of any illegal / prohibited activities such as gambling, drug-trafficking, and firearms.

\subsection{Microfinance and Rivers State}

Amaka (2012), posited that poverty has always been a global issue. Most violent agitations, crimes and other vices have been attributed to poverty. Poverty is a threat to political stability and peace in every society. As part of efforts towards alleviating poverty, governments all over the world, particularly in Africa, have set up programmes geared towards the amelioration of poverty. Rivers state of Nigeria has seen such programmes; unfortunately these programmes were not sustained. However, the disappointment from the failure of previous programmes did not deter the governor of Rivers State, Rt. Hon. Chibuike Rotimi Amaechi, who set out to tackle the arduous task of ameliorating poverty through the establishment of Rivers State Microfinance Agency (RIMA).

Microfinance is the provision of financial services i.e. loans, savings, insurance, or funds transfer services to low-income households. As a tool for helping the poor, Microfinance looks attractive, since it is widely seen as improving livelihoods, reducing vulnerability, and fostering social and economic empowerment. It involves flexible structures and processes by which financial services are delivered to micro-entrepreneur on a sustainable basis. It recognizes the peculiar features and challenges of the poor and micro-entrepreneurs. Little wonder that Governor Chibuike Amaechi decided to tow the way of Professor Mohammad Yunus, founder of Grameen Bank, by establishing RIMA in the fight against poverty.

The Rivers State Microfinance Agency was established in 2008 after Edict No.6 was signed into law. RIMA as an apex institution is a second-tier or wholesale organization that channels fund (loans) to multiple microfinance banks (MBFs) in Rivers state. The essence is to enable easy access to micro-credit and lending to the active poor of Rivers state origin. Victor Halliday served as the pioneer Managing Director/Chief Executive officer of the Agency, and managed its affairs until March, 2010.

In July 2010, Sir Innocent Iyalla Harry took responsibility as Managing Director/Chief Executive Officer of RIMA. By October of the same year the Management team was re-constituted. Today RIMA has a team of Management staff under the leadership of Sir Innocent Harry who are poised to provide guidance, facilitate change, achieve results and meet customers' needs. Regardless of the huge challenges and in a bid to achieve its vision and mission, the Management adopted the wholesale model of disbursing the loan by using direct lending methodology through the microfinance banks in the state, as a medium through which the microentrepreneurs in the state shall access the micro credit facilities.

The selection of participating MFBs in the programme was based on clear criteria such as portfolio quality, dept of outreach, management quality, and progress towards eventual sustainability. The Agency also looked at some global and local challenges of microfinance banks and these were used as basis for prequalification. These challenges include low management capacity, weak corporate governance, high portfolio at risk, non performing loans, high capital impairment, gross under-capitalization, incompetent board, high rate of insider abuses, portfolio mismatch from poor assets-liability management, failure to meet matured obligations, to mention but few.

The prequalification exercise commenced December, 2010. Seven of the microfinance banks operating in Rivers state were successful in the exercise. These include: First Global Microfinance Bank, Golden Choice Microfinance Bank, Cosmopolitan Microfinance Bank, Premium Microfinance Bank, Maxi Trust Microfinance Bank, Iwoama Microfinance Bank and Minjise Microfinance Bank. Each of these banks was assigned to cover some local Government areas of the State.

First Global Microfinance Banks coverd Ahoada East, Ahoada west, Akuku Toru, Degema, Eleme, Etche, Ikwerre, Obio/Akpor, Ogba/Egbema/Ndoni, Oyigbo and Port Harcourt LGAs. Golden Choice 
Microfinance Bank coverd Eleme, Gokana, khana, Oyigbo and Tai LGAs. Cosmopolitan MFB was in charge of Abua/Odual, Ahoada East, Obio/Apkor, Port Harcourt, Andoni, Asari Toru, Bonny and Opobo/Nkoro LGAs. Premium MFB was assigned Eleme, Etche, Obio/Apkor, Port Harcourt and Omuma LGAs. Iwoama Microfinance Bank coverd Okirika and Ogu/Bolo LGAs. Maxitrust took care of Port Harcourt LGA while Minjise Microfinance Bank took care of Port Harcourt, Opobo/Nkoro and Ogu/Bolo LGAs. It is important to note here that the prequalification exercise was still ongoing, and it is hoped that more microfinance banks will join the agency in reaching out to the people.

As the name implies the scheme initiated as a test run to the new product (the wholesale idea); it was intended to guide management decision-making about a broader rollout of the product and to affirm its acceptability. The pilot scheme started in February this 2011. The total sum of three hundred and eight-eight million, six hundred and seventy-seven thousand, five hundred and thirty-one Naira and eighteen kobo ( $388,677,531.18$ ) was so far disbursed in the scheme.

The Agency had a plan of disbursing to 40,000 Rivers State indigenes as beneficiaries by the end of 2011. However, in this first phase of the disbursement, which is considered a pilot scheme, the Agency had a target of reaching out to more than 8,000 beneficiaries proportionately cut across the 23 LGAs of the State.

Due to the recent crackdown by $\mathrm{CBN}$ on Microfinance banks in the country, the number of Microfinance banks available to partner with RIMA in the state was reduced. This limited number of viable MFBs is a constraint for RIMA. Even when broad eligibility criteria were used, only few of initial applications (microfinance bank) qualified for funding. In spite of this constraint, the Agency did not disburse funds to low quality MFBs.

The rural poor constitute both the greatest unmet need and the largest un-served market for Microfinance services. Providing financial services to the rural poor can address problems associated with high levels of poverty, low levels of production, and rural-urban migration. The agency has carried out initial sensitization campaigns to all the Local Government Areas of the State as a way of bridging the gap. However, the response from the target beneficiaries is still low. It is yet to be seen how the MFBs are marketing the products. Some of them are yet to make their presence felt in the local Government Areas assigned to them.

Some of the intended beneficiaries view the loan as government largesse. So when informed that they are expected to repay the loans, they lose interest. Even in the face of these challenges, the Agency is not relenting in its efforts to achieve the set targets. (Nwiyordee, 2012: 50 - 56)

\subsection{Research Design}

\section{Research Methodology}

Research design could be seen as a plan used as a guide in collecting and analyzing the data for a study. It is a model of proof that allows the researcher to draw inferences concerning causal relations among the variables under investigations. (Nachimias and Nachimias, 1976:29) in (Baridam, 2001:51)

Also as posited by Abdellah and Levine (1979:166) in Baridam (2001:51), there are basically two types of research designs, the experimental and quasi-experimental designs. The major difference between them is that in the experimental design, all the elements of the research such as setting, variables, subjects and data collection are largely under the control of the researcher. While in quasi-experimental design, the various research elements are not under the control of the researcher. The former is applied in Natural Sciences researches while the latter is best suited for Administrative or Social Sciences which study human behaviours

This work adopted Sample Survey technique which is an aspect of the Quasi-Experimental design. Under this, questionnaires were administered on the Population which generated the empirical data utilized in testing the hypotheses.

\subsection{Sample Size Determination}

This study was directed at the entire population of 25 licenced Microfinance Banks in Rivers State with a target of 250 respondents cutting across shareholders, management staff, key employees, clients, external auditors and tax consultants with average distribution of 10 respondents per each of the licenced Banks.

\subsection{Data Collection Methods}

For the purpose of testing the hypotheses stated in 1.5 above, primary data were collected through the administering of questionnaire. The questionnaire are designed and sent to randomly selected stakeholders in each of the microfinance banks for their objective responses. The distribution across the length and breadth of the state are quite challenging, a reasonable mile stone was however achieved with the assistance of some helpers engaged for the purpose. The Executives of the Association of Microfinance Banks in Nigeria Rivers Chapter and some field staff of the banks were also of immense help in delivering the questionnaire to the target audience. 
The questionnaire framing took ordinal scales of measurement which enables rank order correlation computation. Telephone interviews, face-to-face conversations and participant observations were also employed to gather more data. Secondary forms of data were equally utilized to complement the Primary data. Both approaches were quite wonderful in facilitating this study.

\subsubsection{Operationalizing the major variables} Independent variable: tax incentives

(i) Five years holidays on company income tax

Dependent Variable: Microfinance Business

(i) Profitability in Microfinance Banks

(ii) Capital formation in Microfinance Banks

(iii) Financial Inclusion Roles of Microfinance Banks

(iv) Credit Delivery in Microfinance Banks

(v) Social Intermediation Roles of Microfinance Banks

\subsubsection{Operationalized Conceptual Framework}

The operationalized conceptual framework of this study is based on a presumed relationship between Tax incentives (independent variable) and Microfinance business in Nigeria (dependent variable). The constructs of tax incentives are income tax holidays, loss reliefs and exempting withholding tax on dividends, clients deposit interests and VAT on microfinance charges; while the microfinance business has capital formation, profitability, financial inclusion, credit delivery and social intermediation as its own constructs. The relationship is moderated by government regulations, technology and clientele

Figure 2: Operationalized Conceptual Framework of Tax Incentives and Microfinance Business

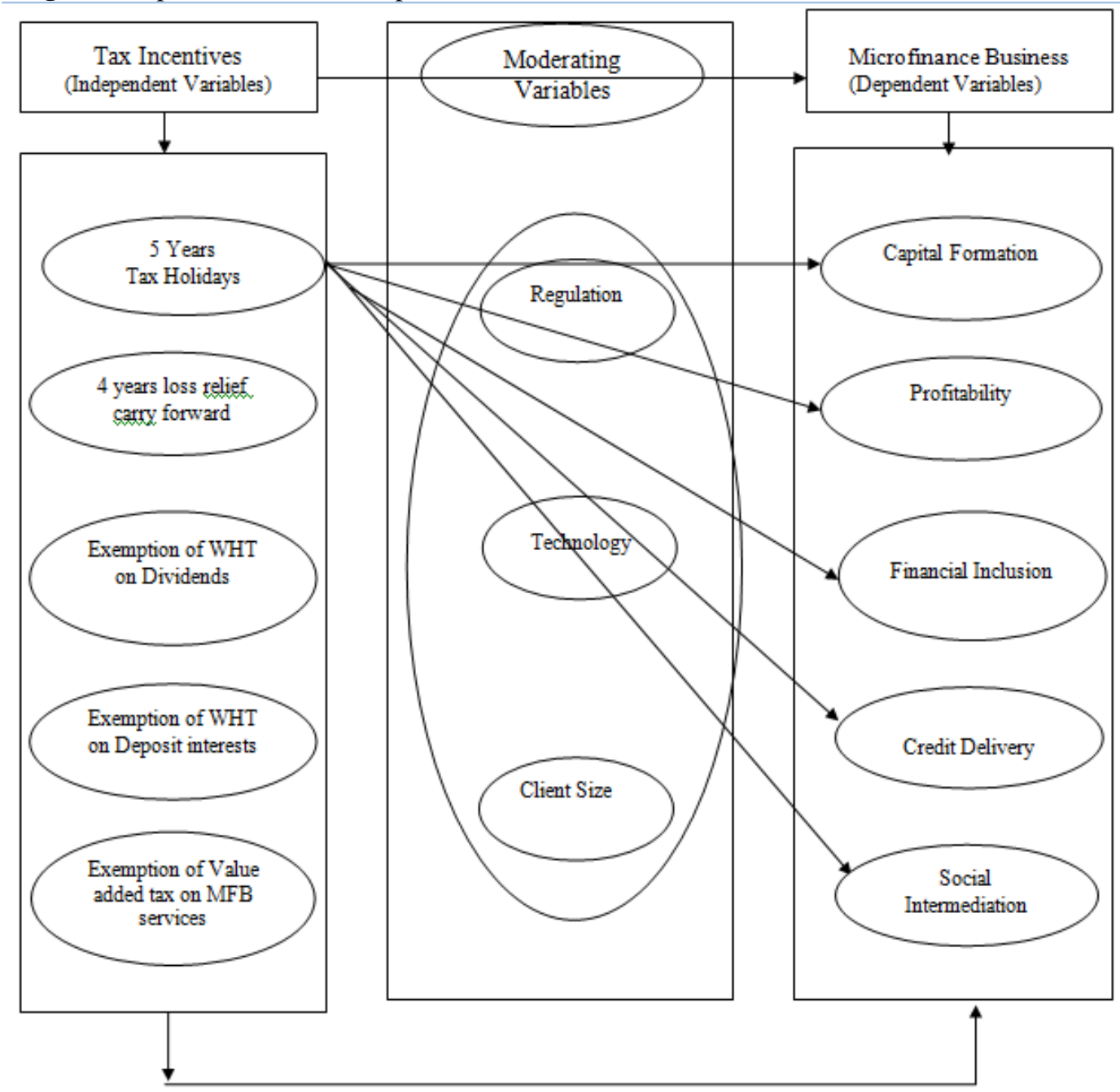

Source: Researchers Conceptualization 2016 


\subsection{Data Analysis Technique}

The Data Analysis technique adopted in this work is the Spearman's Rank Order Correlation Coefficient. It is a non-parametric statistical test which involves little or no assumptions concerning the form of the variables distributions.

The Spearman's rank order correlation is usually designed as Rho. It ranks paired observations, thus requiring at least ordinal data. Rho, symbolized by $\boldsymbol{r s}$ measures the degree of relationship between two sets of ranked observations. It indicates the degree of effectiveness in predicting one ranked variable based on another ranked variable. In this research, the ranked variables are the Five Years Tax Holidays, Exemption of WHT on Dividends, Exemption of WHT on Deposit Interests, Exemption of Value added tax on Microfinance services on one side denoted as Y1, Y2, Y3, and Y4 respectively as well as the Profitability in Microfinance Banks, Capital Formation, Financial Inclusion Roles, Credit Delivery and Social Intermediation Roles of Microfinance Banks denoted as X1, X2, X3, X4 and X5 respectively on another side.

Rho assumes any value from -1 to +1 indicating either imperfect correlation or perfect correlation and 0 indicating no relationship at all. The rank correlation coefficient has the following formula;

$$
r s=1-\quad \frac{6 \sum d^{2}}{N^{3}-N} \text { or } \quad r s=1-\quad \frac{6 \sum d^{2}}{N\left(N^{2}-1\right)}
$$

Where $\sum \boldsymbol{d}^{2}=$ Sum of the squared differences in the ranking of the subject on the two variables.

$N=$ Number of subjects being ranked.

To test the null hypotheses, we introduce the model, $\mathbf{Z}=\boldsymbol{r s} \sqrt{ } \mathbf{N}-\mathbf{1}$.

For a two-tailed test with a 0.05 level of significance, the critical (acceptable) $\mathrm{Z}$ values lie between $\mathbf{- 1 . 9 6}$ and +1.96. If the computed $Z$ value falls between these critical values, each of the null hypotheses will be accepted otherwise they are rejected. (Baridam 2001:155-158)

\subsection{Validity of Research Instrument}

Validity can be defined as the extent to which a test measures what is supposed to be measured. Another term for validity is relevance. The objective of measurement is to determine the true value of the variables for the individuals being measured. There are basically four types of validity each of which is concerned with an aspect of measurement situation: Content Validity, Predictive Validity, Concurrent Validity and Construct Validity. (Baridam 2001:78, 79). This study applied both Content and Construct validity.

Content validity (face and sampling validity) is concerned with the degree to which the sample of test items represents the content that the test is designed to measure. As posited by Cooper and Schindler (2001) in Ironkwe (2011:176), if the instrument of study contains a representative sample of the universe of subject matter of interest, then content validity is good.

In this study, the researcher after designing the questionnaire to measure the relationship between tax incentives and microfinance business reviewed the content of each of the 45 questions and was convinced that they are logically reflective of the study variables. This was further confirmed through the popular opinions expressed to that effect by experts and stakeholders in the subject area. The questionnaire was pretested on microfinance operators, clients and regulators, accountants, tax practitioners, and academics that are not part of the population of the study. Through the pretesting, errors in the questionnaire such as ambiguity, contradictions, poor wordings, misleading or irrelevant instructions among others were detected and eliminated to enhance the content validity.

In the case of Construct Validity, we focus on the degree to which a particular test can measure a hypothetical construct. It involves theorization, drawing of hypotheses, and testing the hypotheses. If the hypotheses are confirmed, one could conclude that the test has construct validity. (Baridam 2001:81). The hypotheses of this study were therefore tested and confirmed thereby boosting its construct validity.

\subsection{Reliability of Research Instrument}

Reliability is defined as the extent to which a measuring instrument is consistent in measuring whatever it measures (Baridam 2001:78). Put differently, a research instrument is said to be reliable if its results are accurate, precise and consistently reproducible.

The reliability of this research instrument was determined through a pilot survey of ten (10) groups made up of ten (10) independent respondents each that cut across academics, accountants, tax practitioners, microfinance operators and clients who are not necessarily part of the study population. Pilot questions were administered on them on two different occasions and a combined data from the scores on tax incentives and the microfinance variables were obtained. 
Tax Incentives \& Microfinance Business In Nigeria: A Study Of Selected Microfinance Banks In ..

The test-retest method of Kendall co-efficient of concordance was adopted to test the data generated which revealed reliability co-efficient of 0.84 indicating a very strong reliability of the research instrument. See Appendix IV.

\section{Introduction}

\section{Presentation, Analysis and Discussion of Results}

This chapter is designed to empirically present and analyze the primary data collected from the respondents as well as testing the eight hypotheses formulated in the study. It is important to recall that the purpose of the research is to evaluate the extent tax incentives could influence microfinance banks in profit making, capital growth, financial inclusion, credit delivery and social intermediation.

A total of 250 questionnaires were produced with a target of administering to at least 10 respondents per each of the 25 licenced microfinance banks in Rivers State. However, only 200 were administered due to accessibility constraints. Of the 200 administered, a total of 145 from 19 Microfinance banks were completed and returned. This represents $72.5 \%$ response rate from the accessible population.

\subsection{Data Presentation}

The questionnaire contains 45 simple and direct questions which are framed to capture respondents' objective rating of tax incentives in relation to how far it could affect the operations of microfinance banks in realizing their core mandates. In line with ordinal scale of measurement, each of the 45 questions contains five rating options lettered $\mathrm{A}, \mathrm{B}, \mathrm{C}, \mathrm{D}$ and $\mathrm{E}$ with corresponding scores thus:

\section{A. \\ B. \\ C. \\ D. \\ E.}

Letter Notation

Total

Rating Options
To a Great Extent
To a Considerable Extent
To a Moderate Extent
To a Slight Extent
Not at all

\section{Scores \\ 4 points \\ 3 points \\ 2 points \\ 1 point \\ 0 point}

Table 2. Summary of ratings obtained from 145 respondents in 19 microfinance banks

\begin{tabular}{|c|c|c|c|c|c|c|c|c|c|c|c|}
\hline 1 & 2 & 3 & 4 & 5 & 6 & 7 & 8 & 9 & 10 & 11 & 12 \\
\hline $\mathrm{S} / \mathrm{N}$ & $\begin{array}{l}\text { MICROFINANCE } \\
\text { BANKS }\end{array}$ & $\begin{array}{l}\text { NO. OF } \\
\text { RESPOND } \\
\text { ENTS }\end{array}$ & $\begin{array}{c}\text { TOTAL } \\
\text { SCORES ON } \\
\text { FIVE YEARS } \\
\text { TAX } \\
\text { HOLIDAYS }\end{array}$ & $\begin{array}{c}\text { TOTAL } \\
\text { SCORES ON } \\
\text { EXEMPTION } \\
\text { OF WHT ON } \\
\text { DIVIDENDS }\end{array}$ & $\begin{array}{c}\text { TOT. } \\
\text { SCORE } \\
\text { ON } \\
\text { EXEMPTI } \\
\text { NG WHT } \\
\text { ON } \\
\text { DEPOSIT } \\
\text { INT. }\end{array}$ & $\begin{array}{c}\text { TOT. } \\
\text { SCORE ON } \\
\text { EXEMPTIN } \\
\text { G WHT ON } \\
\text { LOAN } \\
\text { INTERESTS }\end{array}$ & $\begin{array}{l}\text { TOTAL } \\
\text { SCORE } \\
\text { ON } \\
\text { PROFITAB } \\
\text { ILITY }\end{array}$ & $\begin{array}{c}\text { TOTAL } \\
\text { SCORE } \\
\text { ON } \\
\text { CAPITA } \\
\text { L } \\
\text { FORMA } \\
\text { TION }\end{array}$ & $\begin{array}{c}\text { TOTAL } \\
\text { SCORE } \\
\text { ON } \\
\text { FINANCIA } \\
\text { L } \\
\text { INCLUSIO } \\
\text { N }\end{array}$ & $\begin{array}{c}\text { TOTAL } \\
\text { SCORE } \\
\text { ON } \\
\text { CREDIT } \\
\text { DELIVE } \\
\text { RY }\end{array}$ & $\begin{array}{c}\text { TOTAL } \\
\text { SCORE } \\
\text { ON } \\
\text { SOCIAL } \\
\text { INTER } \\
\text { MEDIA } \\
\text { TION }\end{array}$ \\
\hline 1 & $\begin{array}{c}\text { FIRST GLOBAL } \\
\text { MFB PH }\end{array}$ & 8 & 143 & 125 & 136 & 160 & 155 & 136 & 132 & 166 & 167 \\
\hline 2 & $\begin{array}{l}\text { GOLDEN CHOICE } \\
\text { MFB ELEME }\end{array}$ & 5 & 99 & 75 & 95 & 105 & 92 & 90 & 98 & 105 & 90 \\
\hline 3 & PREMIUMMFB PH & 8 & 162 & 158 & 16 & 184 & 141 & 150 & 132 & 166 & 136 \\
\hline 4 & $\begin{array}{l}\text { COSMOPOLITAN } \\
\text { MFB PH }\end{array}$ & 9 & 170 & 89 & 189 & 216 & 170 & 165 & 158 & 186 & 179 \\
\hline 5 & $\begin{array}{l}\text { U\&CMFB } \\
\text { UNIPORT }\end{array}$ & 15 & 304 & 270 & 37 & 375 & 283 & 277 & 240 & 373 & 299 \\
\hline 6 & $\begin{array}{l}\text { MONEY WELL } \\
\text { MFB PH }\end{array}$ & 6 & 119 & 119 & 108 & 144 & 111 & 108 & 117 & 125 & 119 \\
\hline 7 & $\begin{array}{l}\text { TWOAMA MFB } \\
\text { OKRIKA }\end{array}$ & 8 & 170 & 126 & 136 & 192 & 147 & 148 & 128 & 176 & 159 \\
\hline 8 & LEVITE MFB PH & 6 & 133 & 108 & 108 & 138 & 109 & 125 & 111 & 126 & 119 \\
\hline 9 & $\begin{array}{l}\text { MAXI TRUST MFB } \\
\text { PH }\end{array}$ & 7 & 125 & 114 & 119 & 154 & 136 & 119 & 137 & 160 & 140 \\
\hline 10 & $\begin{array}{l}\text { NEIGHBOURHOO } \\
\text { D MFB PH }\end{array}$ & 8 & 170 & 104 & 160 & 160 & 147 & 158 & 148 & 167 & 159 \\
\hline 11 & OKWUTA MFB PH & 6 & 127 & 95 & 114 & 144 & 110 & 111 & 117 & 125 & 108 \\
\hline 12 & DIOBU MFB PH & 10 & 212 & 189 & 00 & 250 & 183 & 175 & 190 & 220 & 199 \\
\hline 13 & $\begin{array}{l}\text { AHAETO MFB } \\
\text { AKABUKA }\end{array}$ & 5 & 106 & 95 & 105 & 125 & 92 & 92 & 78 & 101 & 95 \\
\hline 14 & MINJISE MFB PH & 6 & 127 & 108 & 20 & 150 & 110 & 111 & 111 & 126 & 102 \\
\hline 15 & $\begin{array}{l}\text { GARDEN CITY } \\
\text { MFB PH }\end{array}$ & 8 & 162 & 136 & 52 & 160 & 146 & 146 & 148 & 167 & 159 \\
\hline 16 & $\begin{array}{c}\text { NKPOLU-UST } \\
\text { MILE } 3 \text { DIOUDU } \\
\text { PH }\end{array}$ & 10 & 200 & 125 & 200 & 210 & 183 & 183 & 165 & 209 & 160 \\
\hline $\begin{array}{l}17 \\
18\end{array}$ & $\begin{array}{l}\text { ROYAL MFB PH } \\
\text { TITARE MFB PH }\end{array}$ & $\frac{6}{8}$ & $\begin{array}{l}127 \\
170\end{array}$ & $\begin{array}{l}110 \\
136\end{array}$ & $\begin{array}{l}132 \\
184\end{array}$ & $\begin{array}{l}132 \\
192\end{array}$ & $\begin{array}{l}110 \\
147\end{array}$ & $\begin{array}{l}110 \\
147\end{array}$ & $\begin{array}{l}117 \\
140\end{array}$ & $\begin{array}{l}125 \\
192\end{array}$ & $\begin{array}{l}108 \\
159\end{array}$ \\
\hline 19 & $\begin{array}{l}\text { SHORELIFE MFB } \\
\text { BORI }\end{array}$ & 6 & 127 & 96 & 120 & 126 & 109 & 111 & 105 & 125 & 113 \\
\hline & TOTAL & 145 & 2,951 & 2,378 & 2,913 & 3,317 & 2,681 & 2,659 & 2,570 & 3,139 & 2,772 \\
\hline
\end{tabular}




\subsection{Data Analysis}

Column 1 of the table shows the serial number, column 2 shows the names of the 19 accessed microfinance banks, column 3 shows the number of respondents per bank - a total of 145 were received. The respondents were randomly selected through simple random sampling technique.

Column 4 presents the total score on the effects of Five years tax holidays objectively determined through its 5 constructs contained in the Section A of the questionnaire accordingly rated on the basis of the 5 given rating criteria. The total score per bank is derived by adding the individual respondents' scores.

In columns 5, 6, 7, 8, 9, 10, 11 and 12 the respondents' total ratings on exemption of withholding tax on dividends, exemption of withholding tax on deposit interests, exemption of Value added tax on microfinance bank services, profitability in microfinance banks, capital formation, financial inclusion, credit delivery and social intermediation are also presented respectively in that order. Similarly, their own assessment criteria are presented in Sections B, C, D, E, F, G, H, and I of the questionnaire in appendix 1.

Columns 4, 5, 6 and 7 therefore measures the independent variables denoted as Y1, Y2, Y3, and Y4 which this study strives to ascertain its degree of relationship with each of the dependent variables denoted as $\mathrm{X} 1, \mathrm{X} 2, \mathrm{X} 3, \mathrm{X} 4$ and $\mathrm{X} 5$ measured in columns 8, 9, 10, 11 and 12 respectively.

\subsection{Discussion of Findings}

The discussion of the findings is done alongside the results obtained in testing of the formulated hypotheses below.

\subsubsection{Testing of Hypotheses}

The scores obtained from the responses to the questionnaire as presented in table 2 above, forms the basis for testing the eight null hypotheses formulated in this research.

The following steps are therefore followed in the test:

i) Statement of the hypothesis

ii) Identification of the test statistic(s)

iii) Specification of the decision rule

iv) Computation based on the test statistic(s)

v) Interpretation

\section{3.2 Statement of Hypotheses}

Eight hypotheses were stated in chapter 1.5 and they are treated one after the other. The hypotheses are

Ho $_{1}$ : $\quad$ Five years tax holidays will not significantly affect the profitability of microfinance banks in Nigeria.

$\mathbf{H o}_{2}$ : Five years tax holidays will not significantly impact on the capital formation of microfinance banks in Nigeria.

$\mathbf{H o}_{3}$ : Five years tax holidays will not significantly enhance the financial inclusion roles of microfinance banks in Nigeria.

Ho $_{4}$ : Five years tax holidays will not significantly enhance the credit delivery of microfinance banks in Nigeria.

Ho s: $_{\text {. }} \quad$ Five years tax holidays will not significantly enhance the social intermediation roles of microfinance banks in Nigeria.

\subsubsection{Identification of Test Statistics}

The statistical tool used in testing these hypotheses is the Spearman's Rank Order Correlation Coefficient and the $\mathrm{Z}$ test. The correlation coefficient measures the degree of relationship between two sets of ranked observations. In this research, the ranked observations (variables) are Five years tax holidays, exemption of WHT on dividends, exemption of WHT on deposit interests, and exemption of Value added tax on Microfinance services on one side denoted as Y1, Y2, Y3, and Y4 and the Profitability, Capital formation, Financial inclusion, Credit delivery and Social intermediation in microfinance banks denoted as X1, X2, X3, X4 and X5 respectively on the other side.

The formula for the rank correlation coefficient is as stated below;

$$
r s=1-\frac{6 \sum d^{2}}{N^{3}-N}
$$

Where $\sum d^{2}=$ Sum of the squared differences in the ranking of the subject on the two variables.

$N=$ Number of subjects being ranked.

The $\mathrm{Z}$ test, with the formula, $\mathbf{Z}=\boldsymbol{r} \boldsymbol{} \sqrt{\mathbf{N}-1}$. is therefore applied in testing the null hypotheses. The computations were done through the SPSS version 17 software program. 
Tax Incentives \& Microfinance Business In Nigeria: A Study Of Selected Microfinance Banks In ..

\section{3.3 Decision Rule}

Using the above formula, if the computed $r s=-1$ it indicates imperfect relationship between independent and dependent variable, if +1 it indicates perfect relationship while 0 indicates no relationship.

In each of the null hypotheses, a two-tailed $Z$ test with a 0.05 level of significance ( $95 \%$ level of confidence), the critical (acceptable) $Z$ values lie between $\mathbf{- 1 . 9 6}$ and $\mathbf{+ 1 . 9 6}$.

If the computed $\mathrm{Z}$ value falls between these critical values, the null hypothesis will be accepted otherwise they are rejected. If a null hypothesis is rejected, the alternate hypothesis will be accepted.

\section{3.4 Computations Based on the Test Statistics}

As analyzed in 4.1 above, the data presented on table 2 form the basis for applying the test statistics. Columns 4 , $5,6,7,8,9,10,11$ and 12 indicate the results of primary data collected from the 145 respondents across 19 microfinance banks operating in Rivers State.

\section{Testing of the First Hypothesis}

The first computation is to test the relationship between Five years tax holidays Y1 (column 4) versus Profitability in Microfinance banks X1 (column 8) presented in table 3 below.

\section{Hypothesis 1}

Ho: $\quad$ Five years tax holidays will not significantly affect the profitability of microfinance banks in Nigeria.

HA $_{1}$ : Five years tax holidays will significantly affect the profitability of microfinance banks in Nigeria.

Using Spearman's Rank Correlation Coefficient computations in SPSS

Version 17 windows output presented in appendix V on page 160;

$$
\begin{array}{ll}
r s & =0.92 \\
Z & =3.9
\end{array}
$$

\section{Interpretation}

Going by the decision rule for a two tailed $Z$ test with a 0.05 level of significance we accept the null hypothesis (Ho) if the calculated $\mathrm{Z}$ value lies between $\pm \mathbf{1 . 9 6}$, i.e. $-\mathbf{Z}$ crit $\square \mathbf{Z}$ cal $\square+\mathbf{Z}$ crit, otherwise it is rejected. From the above computation, the calculated $Z$ value $\mathbf{3 . 9}$ is greater than the Standard $Z$ value of $\pm \mathbf{1 . 9 6}$. Therefore the null hypothesis is rejected. Hence, the alternate hypothesis which states that Five years tax holidays will significantly affect the profitability of microfinance banks in Nigeria is here by accepted. Also a computed correlation coefficient of $\mathbf{0 . 9 2}$ implies a near perfect relationship between Five years tax holidays and profitability of microfinance banks in Nigeria.

\section{Testing Of Second Hypothesis}

The second test of hypothesis is on the relationship between Five years tax holidays Y1 (column 4) versus capital formation in Microfinance banks X2 (column 9) in table 2.

\section{Hypothesis 2}

Ho$_{2}$ : Five years tax holidays will not significantly impact on the capital formation of microfinance banks in Nigeria

$\mathbf{H A}_{2}$ : Five years tax holidays will significantly impact on the capital formation of microfinance banks in Nigeria

Using Spearman's Rank Correlation Coefficient computations in SPSS Version 17 windows output presented in appendix

$$
\begin{array}{ll}
r s & =0.94 \\
Z & =4.0
\end{array}
$$

\section{Interpretation}

Also based on the decision rule for a two tailed $Z$ test with a 0.05 level of significance we accept the null hypothesis (Ho) if the calculated $Z$ value lies between $\pm \mathbf{1 . 9 6}$, i.e. $\mathbf{Z}$ crit $\square \mathbf{Z}$ cal $\square+\mathbf{Z}$ crit, otherwise it is rejected. From the above computation, the calculated $\mathrm{Z}$ value $\mathbf{4 . 0}$ is greater than the Standard $\mathrm{Z}$ value of $\mathbf{\pm 1 . 9 6}$. Therefore the null hypothesis is rejected. Hence, the alternate hypothesis which states that Five years tax holidays will significantly impact on the capital formation of microfinance banks in Nigeria is accepted. The correlation coefficient of $\mathbf{0 . 9 4}$ indicates a strong positive relationship between Five years tax holidays and capital formation of microfinance banks in Nigeria. 
Tax Incentives \& Microfinance Business In Nigeria: A Study Of Selected Microfinance Banks In ..

\section{Testing of Third Hypothesis}

The third hypothesis is on the relationship between Five years tax holidays Y1 (column 4) versus Financial inclusion in Microfinance banks X3 (column 10) in table 2

\section{Hypothesis 3}

Ho $_{3}$ : Five years tax holidays will not significantly enhance the financial inclusion roles of microfinance banks in Nigeria.

$\mathbf{H A}_{3}$ : Five years tax holidays will significantly enhance the financial inclusion roles of microfinance banks in Nigeria.

Using Spearman's Rank Correlation Coefficient computations in SPSS Version 17 windows output presented in appendix.

$$
\begin{aligned}
& r s=0.86 \\
& Z=3.69
\end{aligned}
$$

\section{Interpretation}

Also based on the decision rule for a two tailed $\mathrm{Z}$ test with a 0.05 level of significance we accept the null hypothesis (Ho) if the calculated $Z$ value lies between $\pm \mathbf{1 . 9 6}$, i.e. $-\mathbf{Z}$ crit $\square \mathbf{Z}$ cal $\square+\mathbf{Z}$ crit otherwise it is rejected. From the above computation, the calculated $Z$ value 3.69 is greater than the critical $Z$ value of $\pm \mathbf{1 . 9 6}$. Therefore the null hypothesis is rejected.

The results of $\mathbf{3 . 6 9}$ and $\mathbf{0 . 8 6}$ therefore affirms that there is a significant and positive relationship between Five years tax holidays and financial inclusion roles of Microfinance banks in Nigeria.

\section{Testing of Fourth Hypothesis}

The fourth test of hypothesis is on the relationship between Five years tax holidays Y1 (column 4) and Credit delivery in Microfinance banks X4 (column 11) in table 2.

\section{Hypothesis 4}

$\mathbf{H o}_{4}$ : $\quad$ Five years tax holidays will not significantly enhance the credit delivery of microfinance banks in Nigeria.

$\mathbf{H A}_{\mathbf{4}}$ : Five years tax holidays will significantly enhance the credit delivery of microfinance banks in Nigeria. Using Spearman's Rank Correlation Coefficient computations in SPSS Version 17 windows output presented in appendix;

$$
\begin{aligned}
& r s=0.95 \\
& Z=4.0
\end{aligned}
$$

\section{Interpretation}

Also based on the decision rule for a two tailed $\mathrm{Z}$ test with a 0.05 level of significance we accept the null hypothesis (Ho) if the calculated $\mathbf{Z}$ value lies between $\pm \mathbf{1 . 9 6}$, i.e. $-\mathbf{Z}$ crit $\square \mathbf{Z}$ cal $\square+\mathbf{Z}$ critotherwise it is rejected. From the above computation, the calculated $Z$ value $\mathbf{4 . 0}$ is greater than the critical $Z$ value of $\pm \mathbf{1 . 9 6}$. Therefore the null hypothesis is rejected. The results of $\mathbf{4 . 0}$ and $\mathbf{0 . 9 5}$ therefore affirms that there is a significant and positive relationship between Five years tax holidays and Credit delivery services of Microfinance banks in Nigeria.

\section{Hypothesis 5}

Ho $_{5}$ : Five years tax holidays will not significantly enhance the social intermediation roles of microfinance banks in Nigeria.

HA $_{5}$ : Five years tax holidays will significantly enhance the social intermediation roles of microfinance banks in Nigeria.

Using Spearman's Rank Correlation Coefficient computations in SPSS Version 17 windows output presented in appendix

$$
\begin{array}{ll}
r s & =0.87 \\
Z & =4.09
\end{array}
$$




\section{Interpretation}

Also based on the decision rule for a two tailed $Z$ test with a 0.05 level of significance we accept the null hypothesis (Ho) if the calculated $Z$ value lies between $\pm \mathbf{1 . 9 6}$, i.e. $-\mathbf{Z}$ crit $\square \mathbf{Z}$ cal $\square+\mathbf{Z}$ crit otherwise it is rejected. From the above computation, the calculated $Z$ value 4.09 is greater than the critical $Z$ value of $\pm \mathbf{1 . 9 6}$. Therefore the null hypothesis is rejected. The results of $\mathbf{4 . 0 9}$ and $\mathbf{0 . 8 7}$ therefore affirms that there is a significant and positive relationship between Five years tax holidays and Social intermediation roles of Microfinance banks in Nigeria.

\section{Introduction}

\section{Summary, Conclusions \& Recommendations}

This is the final chapter of the research work where the summary of findings are presented, conclusion drawn and recommendations made.

\subsection{Summary of Findings}

The purpose of this study is to empirically ascertain the extent to which tax incentives could influence microfinance business in Nigeria in the areas of profit making, capital formation, credit delivery, financial inclusion and social intermediation. Relevant theoretical and empirical literature on taxation, tax incentives and microfinance activities were reviewed to give sufficient background to the study.

Primary data were collected from operators and clients of Microfinance Banks in Rivers State. The data collected were analyzed and tested with Spearman's Correlation Coefficient tool and Z test. The results of the tests enabled the following findings;

1) That tax holidays has positive and significant relationship with profitability and sustainability of microfinance banks in Nigeria

2) That tax holidays has positive and significant relationship with the capital formation of microfinance banks in Nigeria

3) That tax holidays has positive and significant relationship with the financial inclusion roles of microfinance banks in Nigeria

4) That tax holidays has positive and significant relationship with the credit delivery of microfinance banks in Nigeria

5) That tax holidays has positive and significant relationship with the social intermediation roles of microfinance banks in Nigeria

\subsection{Conclusions}

5.2.1 Tax is a compulsory payment imposed by government on her citizens without a corresponding quid pro $q u o$. It is the major revenue source of the federal, state and local governments derived from individuals, groups of individuals, corporate residents and other legal entities. However, tax incentives refer to government policies which reduce or eliminate tax obligations of tax payers. Microfinance on the other hand means simple, flexible and sustainable financial services rendered to the active poor and low income earners on a continuous and competitive manner. Microfinance Bank is a company licenced to carry out microfinance business.

5.2.2 The research was practically carried out to measure the relationship between tax incentives and microfinance business in Nigeria. The results of the measurements in chapter four based on the opinions expressed by questionnaire respondents using Spearman's Correlation Coefficient lends credence to a generalization that tax incentives would significantly add values to the Microfinance Banks in the areas of capital formation, profitability, financial inclusion, credit delivery and social intermediation

5.2.3 Despite high tax burdens, other factors that militate against effective and efficient operation of Microfinance Banks in Nigeria are harsh economy, weak infrastructure, wrong selection of clients, loan repayment defaults, weak equity base, poor corporate governance, lack of modern technology, lack of appropriate risk management, inappropriate internal systems and structures, low awareness by general public, stiff competitions and dearth of adequate manpower.

\subsection{Recommendations}

The following recommendations are therefore made by the researcher based on the foregoing findings:

1) Government at all levels should see Microfinance Banks as Change

Agents in the poverty eradication, job creation and financial inclusion crusades therefore, should be granted five years tax incentives especially at the infancy and vulnerable stages of their existence so as to engender sound footings for the herculean tasks ahead. If Commercial Banks, Bank of Industry (BOI) and Manufacturers Association of Nigeria (MAN) with high capital base could be bailed out by government at one time or another, why not Microfinance Banks through tax incentives? . 
2) The accounting and legal framework to compel State and Local governments to earmark $1 \%$ of their annual budgets for Microfinance Development Fund should be pursed to logical conclusion by the relevant organs of government. This will no doubt expand the funding of the Microfinance Institutions.

3) The Regulators, CBN and NDIC should always provide level playing fields and enabling environment for the Microfinance Banks to thrive well.

4) The Microfinance Investors on their own part should improve on the private funding of their institutions so as to fast track capital formations and better capital adequacy positions.

5) Also, only qualified and credible Directors and Managers should be hired to drive the Microfinance Institutions so as to achieve best practices in corporate governance, technology, internal controls and risk management for positive results.

6) Regular training and retraining of the Microfinance Regulators, Directors, Managers and Operators should be sustained so as to continuously eliminate capacity and manpower gaps in the sub-sector.

7) The Microfinance Operators should ensure right selection and sensitization of their clients so as to overcome the serious challenge of loan delinquencies and defaults. In this regard, group lending methodologies should be given priority.

8) Aggressive marketing of their services to the general public should also not be overlooked so as to reasonably penetrate the target market for patronage; this will help to ward off stiff competitions from Deposit Money Banks.

9) The Microfinance Banks should maintain high ethical standards and keep correct financial records so as to maintain reasonable level of integrity.

10) The Microfinance Banks should embrace annual tax planning as a way of managing their tax burdens with or without tax incentives.

11) The Microfinance Banks should also embrace enterprise risk management as a way of managing their various risks

\subsection{Contributions to Knowledge}

Microfinance practices are not new globally but its formalized and regulated form is relatively new in Nigeria. This regulated regime clearly defined the mandates of the Microfinance Institutions (MFIs) which revolves around taking banking services to the grassroots for the economic empowerment of the active poor. Recent studies on other aspects of taxation focused on sectors such as oil and gas, manufacturing, agribusiness and conventional banks. But this work which focused on ascertaining how well tax incentives could boost the sustainability of microfinance business in Nigeria is a pathfinder in the subject area. It is a foundation upon which further researches shall be built upon.

The recommendations in this study would provide veritable insight to Professional bodies like The Institute of Chartered Accountants of Nigeria (ICAN), Chartered Institute of Taxation of Nigeria (CITN), Chartered Institute of Bankers of Nigeria (CIBN) and Association of Microfinance Banks in Nigeria (AMBIN) in the performance of their roles.

Regulators such as the Central Bank of Nigeria (CBN) and Nigeria Deposit Insurance Corporation (NDIC) that advocate for financial inclusion and sound financial system shall see the results of this research as a reasonable ground to push for tax incentives in the microfinance sub-sector because it is still at its infancy and vulnerable stage. Also, through the study, Nigerian government on its part in pursuit of poverty and unemployment reduction programmes shall see the need to grant tax incentives to the grass root financial institutions that should be at the front seat in driving the programmes. Also, international donor or lending agencies investing or intending to invest in poverty eradication and job creation schemes in Nigeria would find this piece of work a useful tool.

The conceptual frame work presented in chapter 1.5 and the conceptual model (figure 1) coupled with the empirical results of the study shall add to the existing scanty literature in taxation and microfinance business and therefore, would be a reference point for academic journals, lecturers and fellow students in the School of Business with specialization in accountancy, finance and economics.

The Contextual model in itself offers a new perspective to the investigation and explanation of the fact that tax incentives has positive and strong impact on the sustainability of Microfinance Banks in Nigeria irrespective of the effects of the moderating variables.

\subsection{Suggestions for Further Studies}

This work which focused on ascertaining the extent tax incentives could boost sustainability of microfinance banks in Nigeria is a pathfinder in the subject area and a foundation upon which further studies shall be built upon. It is therefore suggested that similar research should be conducted in other social oriented sectors such as Primary Mortgage Institutions (PMIs), Private Health Institutions, Food Vending and allied firms to validate the findings of this research. 
It is also suggested that when the Microfinance Banks become fully developed and less vulnerable in future, the same research on tax incentives should be conducted to ascertain whether the new findings will be different from the present one and to what extent.

Due to adoption of International Financial Reporting Standards (IFRS) by Banks in Nigeria in 2012, it is suggested that a research should be carried out on the Tax implications of IFRS on Microfinance Banks in Nigeria. Other areas suggested for future studies are appraisal of Tax avoidance and Tax incentives impacts on Nigerian Banks, Internal Control System and Fraud Prevention in Microfinance Banks, Electronic Accounting System and Financial Reporting in Other Financial Institutions in Nigeria.

\section{References}

[1]. Abdellah, F. G. and Levine, E. (1979), Better Patient Care Through Nursing Research, New York: Macmillan Publishing Co.

[2]. Adedokun, P. (2001), Reforming Nigeria's incentive system, Quarterly Journal of Administration (University of Ife), vol. 4, July p. $421-426$.

[3]. Agiobenebo, T. J, Onuchukwu, O. and Ajie, H. A. (2003), Public Sector Economics: Theories, Issues and Applications, $3^{\text {rd }}$ Edition, Port Harcourt, Lima Computers.

[4]. Akun, Jethro M. (2013), The State of microfinance Banks in Nigeria: Challenges and Prospects, being a paper presented as the president of National Association of Microfinance Banks in Nigeria (NAMB) at an executive round table briefing on banking ethics and values for rural transformation through Microfinance Banks and Industrial Development Cooperatives on 13/08/2013 in Abuja Nigeria.

[5]. Amaka, P. (2012), RIMA Uplift Rivers People from Poverty, RIMA News, Rivers State Publication.

[6]. Anyafo, A. M. O. (1996), Public Finance in a Developing Economy, The Nigerian Case, $1^{\text {St }}$ Edition, B \& F Publications, University of Nigeria Enugu Campus.

[7]. Asiegbu, I. (2007), Lecture Notes on Business Research Methods, Unpublished Text, Department of Marketing, University of Port Harcourt Nigeria.

[8]. Bangladesh Extension Education Services (2001) "Empowering Women through Microfinance"

[9]. Baridam, D.M. (2001), Research Methods in Administrative Sciences, ${ }^{\text {rd }}$ Edition, Port Harcourt: Sherbrooke Associates.

[10]. Browning, E. K. and Browning, J.M. (1979), Public Finance And The Price System, New York, Macmillan Publishing Co. Inc.

[11]. CBN and NDIC (2011), Microfinance Certification Programme Revised Study Manual, CIBN Press Limited, Lagos

[12]. Central Bank of Nigeria (2005): Microfinance Policy Regulatory and Supervisory framework for Nigeria, Adgozo Ltd. (Press Division), Onitsha.

[13]. Central Bank of Nigeria (2012), Revised Regulatory and Supervisory Guidelines for Microfinance Banks in Nigeria, Abuja Nigeria.

[14]. Cooper, D. R. and Schindler, P.S. (2001), Business Research Methods, New York: Irwin, McGraw-Hill.

[15]. Dalton, Hugh (1964), Principles of Public Finance, London, Routledge \& Kegan Paul Ltd.

[16]. Ehigiamusoe, G. (2000), Poverty and Microfinance in Nigeria, Ob-Zed publishers, 7 Triangle Avenue, off Urubi street, Benin city, Edo State Nigeria.

[17]. Ehigiamusoe, G. (2005), Micro credit: Tool for Poverty Alleviation, a paper presented at the $12^{\text {th }}$ Annual LAPO development forum in Benin City on Monday October 17, 2005.

[18]. Ehigiamusoe, G. (2005), Tested Institutional Practice for Efficient Microfinance Service Delivery, CBN Proceedings at the launching of the Microfinance Policy, Regulatory and Supervisory Framework for Nigeria, Abuja.

[19]. Ehigiamusoe, G. (2008), Delinquency Management in Microfinance, the Nigerian Microfinance Newsletter, January-June CBN Abuja.

[20]. Ehigiamusoe, G. (2011), Issues in Microfinance, Enhancing Financial Inclusion, mindex publishing company limited.

[21]. Ekundare, R. O. (1970), "The Evolution of Nigeria's Income Tax Systems from Colonial Period to 1945", The Quarterly Journal of Administration (University of Ife), vol. 4, No. 3 (July) pp. 255 - 267.

[22]. Ezirim, C.B. (2005), Finance Dynamics: Principles, Techniques And Applications, 3rd Edition, Markowitz Centre for Research and Development, Port Harcourt

[23]. Gberegbe, F.B. (2007), Tax Administration in Nigeria (Concepts and Practice), Fredsbary Printers \& Publishers, Bori, Nigeria

[24]. Hanson, J. L. (1974), A Dictionary of Economics And Commerce, London, Macdonald and Evans Ltd

[25]. Ironkwe, I. U. (2011), The Impact of Taxation on Corporate Financial Performance: A Study of Quoted Agribusiness Companies in Nigeria, being a PhD Thesis submitted to Department of Accounting University of Port Harcourt

[26]. Ledgerwood, J. (1998), Sustainable Banking with the Poor, Microfinance Handbook: An Institutional and Financial Perspective. The International Bank for Reconstruction and Development, 1818H Street, N.W Washington D.C 20433, U.S.A

[27]. Marguerite, R. S. (2001), The Microfinance Revolution, Sustainable Finance for the Poor. The World Bank, Washington D.C, Open Society Institute, New York.

[28]. Nachmias, D. and Nachmias, C. (1976), Research Methods in the Social Sciences, UK: Edward Arnold

[29]. Nwakadu, Ogunmola and Oroleye (2011), 5 years of Microfinance Practice in Nigeria: Which Way Forward? Microfinance Searchlight $5^{\text {th }}$ Edition, Quarterly Publication of Hasal Microfinance Bank Limited, Abuja.

[30]. Nwiyordee, A. N. (2012), Economic Empowerment Analysis of Microfinance Operations: A study of selected microfinance institutions in Rivers State, being M.Sc Thesis submitted to Department of Finance \& Banking

[31]. Okauru, Ifueko (2009), Tax Incentives for Foreign Investors in Nigeria, being a paper presented as the Chairman, Federal Inland Revenue Service and Joint Tax Board at the Nigeria Investors Business Forum, Berne Switzerland on $20^{\text {th }}$ and $21^{\text {st }}$ November, 2009

[32]. Osuji, E. (2005), Microfinance and Economic Activity, Breaking the Poverty Chain, Gold Press Limited, Ibadan

[33]. Prest, A. R. (1975), Public Finance in Theory and Practice, London, Wei den field And Nicolson

[34]. Stephen, N. M. and Osagie, E. (1985), A Textbook of Economics for West African Students, Ibadan, University Press Ltd.

[35]. Udeme, E. (2012), LAPO MFB's lending, the Punch Newspaper, Wednesday September 19, 2012.

[36]. UNDP (1998), Nigerian Human Development report, Lagos.

[37]. Williams, R. G. (1975), Comprehensive Aspects of Taxation, Reading, Donnington Press. 
Tax Incentives \& Microfinance Business In Nigeria: A Study Of Selected Microfinance Banks In ..

\section{APPENDIX I}

\section{SPSS VERSION 17 COMPUTATION ON TAX INCENTIVES AND CAPITAL FORMATION}

SAVE OUTFILE='C:IDocuments and Settings\AdministratorlMy DocumentsINNAJI-1.sav' /COMPRESSED. NONPAR CORR /VARIABLES=TOTAL SCORE ON TAX INCENTIVES

TOTAL_SCORFE_ON_CAPITAL_FORMATION /PRINT=SPEARMAN TWOTAIL SIG

/MISSING=PAIRWISE.

Nonparametric Correlations

[DataSet0] C: Documents and Settings\AdministratorlMy Documents\NNAJI-1.sav

\begin{tabular}{|c|c|c|c|c|}
\hline \multicolumn{5}{|c|}{ Correlations } \\
\hline & & & $\begin{array}{l}\text { TOTAL_SCORE_ON } \\
\text { _TAX_INCENTIVES }\end{array}$ & $\begin{array}{c}\text { TOTAL_SCORFE_O } \\
\text { N_CAPITAL_FORM } \\
\text { ATION }\end{array}$ \\
\hline \multirow[t]{2}{*}{ Spearman's rho } & $\begin{array}{l}\text { TOTAL_SCORE_ON_TAX_INCE } \\
\text { NTIVES }\end{array}$ & $\begin{array}{l}\text { Correlation Coefficient } \\
\text { Sig. (2-tailed) } \\
\mathrm{N} \\
\end{array}$ & $\begin{array}{r}1.000 \\
. \\
19 \\
\end{array}$ & $\begin{array}{r}.874 \\
.000 \\
19 \\
\end{array}$ \\
\hline & $\begin{array}{l}\text { TOTAL_SCORE_ON_CAPITAL_F } \\
\text { ORMATION }\end{array}$ & $\begin{array}{l}\text { Correlation Coefficient } \\
\text { Sig. (2-tailed) } \\
\mathrm{N}\end{array}$ & $\begin{array}{r}.874 \\
.000 \\
19\end{array}$ & $\begin{array}{r}1.000 \\
19 \\
.\end{array}$ \\
\hline
\end{tabular}

\begin{tabular}{|l|r|r|}
\hline$z$-Test: Two Sample for Means & & \\
\cline { 1 - 2 } & $\begin{array}{c}\text { TOTAL SCORE ON TAX } \\
\text { INCENTIVES }\end{array}$ & $\begin{array}{c}\text { TOTAL SCORE ON CAPITAL } \\
\text { FORMATION }\end{array}$ \\
\hline Mean & 327.3015789 & 294.89 \\
\hline Known Variance & 2170 & 1871 \\
\hline Observations & 19 & 19 \\
\hline Hypothesized Mean Difference & 1 & \\
\hline$Z$ & 2.153883169 & \\
\hline$P(Z<=z)$ one-tail & 0.015624668 & \\
\hline z Critical one-tail & 1.644853627 & \\
\hline P(Z<=z) two-tail & 0.031249335 & \\
\hline$z$ Critical two-tail & 3.6012085 & \\
\hline
\end{tabular}

\section{APPENDIX II}

SPSS VERSION 17 COMPUTATION ON TAX INCENTIVES AND PROFITABILITY IN MFBS Nonparametric Correlations

\begin{tabular}{|c|c|c|c|c|}
\hline \multicolumn{5}{|c|}{ Correlations } \\
\hline & & & \begin{tabular}{|l|} 
TOTAL_SCORE_ON \\
TAX_INCENTIVES
\end{tabular} & $\begin{array}{l}\text { TOTAL_SCORE_PR } \\
\text { OFITABILITY }\end{array}$ \\
\hline \multirow[t]{6}{*}{ Spearman's rho } & \multirow{3}{*}{$\begin{array}{l}\text { TOTAL_SCORE_ON_TAX_INCEN } \\
\text { TIVES }\end{array}$} & Correlation Coefficient & 1.000 & .862 \\
\hline & & Sig. (2-tailed) & & \\
\hline & & $\mathrm{N}$ & 6218 & 6218 \\
\hline & \multirow[t]{3}{*}{ TOTAL_SCORE_PROFITABILITY } & Correlation Coefficient & .862 & \multirow[t]{3}{*}{1.000} \\
\hline & & Sig. (2-tailed) & .000 & \\
\hline & & $\mathrm{N}$ & 6218 & \\
\hline
\end{tabular}

\begin{tabular}{|l|r|r|}
\hline$z$-Test: Two Sample for Means & & \\
\hline & $\begin{array}{r}\text { TOTAL SCORE ON } \\
\text { TAX INCENTIVES }\end{array}$ & $\begin{array}{c}\text { TOTAL SCORE ON } \\
\text { PROFITABILITY }\end{array}$ \\
\hline Mean & 327.3016 & 296.3873684 \\
\hline Known Variance & 2170 & 1757 \\
\hline Observations & 19 & 19 \\
\hline Hypothesized Mean Difference & 1 & \\
\hline $\mathrm{Z}$ & 2.080769 & \\
\hline $\mathrm{P}(\mathrm{Z}<=\mathrm{z})$ one-tail & 0.018728 & \\
\hline $\mathrm{z}$ Critical one-tail & 1.644854 & \\
\hline $\mathrm{P}(\mathrm{Z}<=\mathrm{z})$ two-tail & 0.037455 & \\
\hline $\mathrm{z}$ Critical two-tail & 3.310154 & \\
\hline
\end{tabular}




\section{APPENDIX III}

\section{SPSS VERSION 17 COMPUTATION ON TAX INCENTIVES AND FINANCIAL INCLUSION}

Nonparametric Correlations

\begin{tabular}{|c|c|c|c|c|}
\hline \multicolumn{5}{|c|}{ Correlations } \\
\hline & & & $\begin{array}{l}\text { TOTAL_SCORE_ON } \\
\text { _TAX_INCENTIVES }\end{array}$ & $\begin{array}{c}\text { TOTAL_SCORE_ON } \\
\text { _FINANCIAL_INCL } \\
\text { USION }\end{array}$ \\
\hline \multirow[t]{6}{*}{ Spearman's rho } & \multirow{3}{*}{$\begin{array}{l}\text { TOTAL_SCORE_ON_TAX_INCEN } \\
\text { TIVES }\end{array}$} & & 1.000 & .747 \\
\hline & & Sig. (2-tailed) & & .000 \\
\hline & & $\mathrm{N}$ & 6218 & 6218 \\
\hline & \multirow{3}{*}{$\begin{array}{l}\text { TOTAL_SCORE_ON_FINANCIAL_ } \\
\text { INCLUSION }\end{array}$} & Correlation Coefficient & .747 & 1.000 \\
\hline & & Sig. (2-tailed) & .000 & \\
\hline & & $\mathrm{N}$ & 6218 & 6218 \\
\hline
\end{tabular}

z-Test: Two Sample for Means

\begin{tabular}{l|r|r|}
\cline { 2 - 3 } & $\begin{array}{c}\text { TOTAL } \\
\text { SCORE ON } \\
\text { TAX } \\
\text { INCENTIVE } \\
\text { S }\end{array}$ & $\begin{array}{c}\text { TOTAL } \\
\text { SCORE ON } \\
\text { FINANCIAL } \\
\text { INCLUSION }\end{array}$ \\
\hline Mean & 327.3015789 & 285.8421053 \\
Known Variance & 2170 & 1253.8 \\
Observations & 19 & 19 \\
Hypothesized Mean Difference & 1 & \\
$\mathrm{Z}$ & 3.013997138 & \\
$\mathrm{P}(\mathrm{Z}<=\mathrm{z})$ one-tail & 0.001289151 & \\
$\mathrm{z}$ Critical one-tail & 1.644853627 & \\
$\mathrm{P}(\mathrm{Z}<=\mathrm{z})$ two-tail & 0.002578302 & \\
$\mathrm{z}$ Critical two-tail & 3.7339850 & \\
\hline
\end{tabular}

\section{APPENDIX IV}

SPSS VERSION 17 COMPUTATION ON TAX INCENTIVES AND CREDIT DELIVERY IN MFBS Nonparametric Correlations

\begin{tabular}{|c|c|c|c|c|}
\hline \multicolumn{5}{|c|}{ Correlations } \\
\hline & & & $\begin{array}{l}\text { TOTAL_SCORE_ON } \\
\text { _TAX_INCENTIVES }\end{array}$ & $\begin{array}{l}\text { TOTAL_SCORE_ON } \\
\text { _CREDIT_DELIVER } \\
\text { Y }\end{array}$ \\
\hline \multirow[t]{3}{*}{ Spearman's rho } & $\begin{array}{l}\text { TOTAL_SCORE_ON_TAX_INCEN } \\
\text { TIVES }\end{array}$ & $\begin{array}{l}\text { Correlation Coefficient } \\
\text { Sig. (2-tailed) } \\
\mathrm{N}\end{array}$ & $\begin{array}{r}1.000 \\
6218\end{array}$ & $\begin{array}{r}.877 \\
.000 \\
6218\end{array}$ \\
\hline & $\begin{array}{l}\text { TOTAL_SCORE_ON_CREDIT_DEL } \\
\text { IVERY }\end{array}$ & $\begin{array}{l}\text { Correlation Coefficient } \\
\text { Sig. (2-tailed) }\end{array}$ & $\begin{array}{l}.877 \\
.000\end{array}$ & 1.000 \\
\hline & & $\mathrm{N}$ & 6218 & 6218 \\
\hline
\end{tabular}

\begin{tabular}{|c|c|c|}
\hline z-Test: Two Sample for Means & & \\
\hline & $\begin{array}{l}\text { TOTAL SCORE ON TAX } \\
\text { INCENTIVES }\end{array}$ & $\begin{array}{l}\text { TOTAL SCORE ON } \\
\text { CREDIT DELIVERY }\end{array}$ \\
\hline Mean & 327.3015789 & 332.4236842 \\
\hline Known Variance & 2170 & 2092 \\
\hline Observations & 19 & 19 \\
\hline Hypothesized Mean Difference & 1 & \\
\hline $\mathrm{Z}$ & -0.408762334 & \\
\hline $\mathrm{P}(\mathrm{Z}<=\mathrm{z})$ one-tail & 0.341357042 & \\
\hline z Critical one-tail & 1.644853627 & \\
\hline $\mathrm{P}(\mathrm{Z}<=\mathrm{z})$ two-tail & 0.682714084 & \\
\hline z Critical two-tail & 3.6900448 & \\
\hline
\end{tabular}

